\title{
Een exploratief onderzoek naar de accepteerbaarheid van industriële cobots bij
} (toekomstige) operatoren. ${ }^{1}$

Bram B. Van Acker, Peter D. Conradie, Davy D. Parmentier, Jamil Joundi, Jelle Saldien, Peter Vlerick*

\section{Author accepted manuscript}

*Bram B. Van Acker en Jamil Joundi zijn verbonden aan de onderzoeksgroep imec-mictugent en aan de Vakgroep Industriële Systemen en Productontwerp, Universiteit Gent. Davy D. Parmentier is verbonden aan de onderzoeksgroep design.nexus en aan de Vakgroep Industriële Systemen en Productontwerp, Universiteit Gent.

Peter D. Conradie is verbonden aan de onderzoeksgroep imec-mict-ugent en aan de Vakgroep Industriële Systemen en Productontwerp, Universiteit Gent.

Jelle Saldien is verbonden aan de onderzoeksgroep imec-mict-ugent en aan de Vakgroep Industriële Systemen en Productontwerp, Universiteit Gent, Peter Vlerick is verbonden aan de Vakgroep Werk, Organisatie en Samenleving, Universiteit Gent, België.

Correspondentieadres: Bram B. Van Acker, De Krook, Miriam Makebaplein, 1, B-9000 Gent, 0032-9-2649707, bramb.vanacker@ugent.be,. 


\section{Samenvatting}

Collaboratieve robots (cobots) zullen een prominente plaats innemen op de productievloer van de aankomende vierde industriële revolutie. Het is vandaag echter onbekend hoe operatoren zich positioneren ten aanzien van deze cobot(r)evolutie. Deze exploratieve studie onderzocht met een vragenlijst en een kort semi-gestructureerd interview de ervaren baanbedreiging door en accepteerbaarheid van cobots en cobotfunctionaliteiten bij (toekomstige) operatoren $(N=$ 83). De resultaten wezen op een beperkte aanvankelijk ervaren baanbedreiging. Deze ervaring steeg wel significant op het einde van de vragenlijst - waar de participanten intussen meer hadden geleerd over cobots - naar een nog steeds neutrale score, mogelijk omdat (toekomstige) operatoren twijfelen aan de betrouwbaarheid en capaciteiten van cobots. Daarnaast werd een hogere accepteerbaarheid gevonden voor cobotfunctionaliteiten die fysieke werktaken en kwaliteitscontrole omvatten, terwijl cognitief geavanceerde en adaptieve cobots eerder een neutrale accepteerbaarheid uitlokte. De algemene accepteerbaarheid van cobots was voor de operatoren eerder positief. Opmerkelijk, toekomstige operatoren (studenten) scoorden significant wat lager voor de meeste studievariabelen in vergelijking met actueel tewerkgestelde operatoren. Beperkingen en implicaties voor de accepteerbaarheid en acceptatie van deze veelbelovende technologie worden geformuleerd. 


\section{Introductie}

De huidige industriële werkplek van producerende bedrijven en organisaties (ook wel benoemd als de 'maakindustrie' of de 'manufacturing industry'), maakt een gestage evolutie door van een routinematige werkplek gebaseerd op massaproductie naar een werkomgeving waarin veel kleine oplages van verschillende versies van een bepaald product worden vervaardigd (Bläsing, Hinrichsen, \& Bornewasser, 2020). De toekomstige werkvloer zal als gevolg gekenmerkt worden door een toegenomen variëteit in producten en de hiervoor benodigde productiecomplexiteit en flexibiliteit (Um, Lyons, Lam, Cheng, \& Dominguez-Pery, 2017; Wan \& Sanders, 2017). Om deze evolutie mogelijk te maken wordt in toenemende mate technologie ingezet ter automatisatie van deze complexer wordende werkomgeving en bovendien ter ondersteuning van de werknemers (d.w.z. operatoren). Van de toekomstige operator zal niettemin meer flexibiliteit en cognitieve arbeid worden verwacht (Booker, Swift, \& Brown, 2005; Xu, Xu, \& Li, 2018). Verwacht kan worden dat deze technologische (r)evolutie zo een sterke impact heeft en zal hebben op de baaninvulling en arbeidsbeleving van zowel de momenteel tewerkgestelde operatoren als de toekomstige operatoren. Inderdaad, verschillende nieuwe geavanceerde technologieën, zoals augmented reality instructies (d.m.v. slimme brillen of projectie op werkstukken) (Bläsing et al., 2020) of virtual reality training (d.w.z. het aanleren van taken in de virtuele realiteit) (Al-ahmari, Abidi, \& Ahmad, 2016) zullen een toegewijde inspanning vergen van deze operator. De huidige studie zal focussen op een andere centrale en veelbelovende technologische ontwikkeling, met name cobot-technologie. Studie van deze technologie is belangrijk ondermeer doordat deze technologie niet alleen kan worden ingezet ter ondersteuning van de operator doch ook doordat deze het takenpakket van de operator an sich sterk wijzigt.

\subsection{Industrie 4.0}


De huidige en toekomstige werkomgeving van verhoogde productiecomplexiteit enerzijds en doorgedreven digitale technologie ter automatisatie, connectivering van fysische technologie en ondersteuning van de operator anderzijds, wordt ook wel de Industrie 4.0 genoemd (Brolin, Thorvald, \& Case, 2017; Erol, Jäger, Hold, Ott, \& Sihn, 2016; Longo, Nicoletti, \& Padovano, 2017; Shalin, Prabhu, \& Helander, 1996; Xu et al., 2018; Young, Brookhuis, Wickens, \& Hancock, 2014). Deze fase, in de bedrijfspraktijk soms ook benoemd als 'smart industry' of de vierde industriële revolutie, volgt op de drie voorgaande industriële revoluties gedreven door respectievelijk mechanisatie (d.m.v. stoom en waterkracht), massaproductie (d.m.v. elektriciteit) en automatisatie (d.m.v. computers en andere elektronica) (Oztemel \& Gursev, 2020). Technologieën die voor deze transitie zorgen zijn, o.a., The Internet of Things and Services (d.w.z. de onderlinge connectie van apparaten en werktuigen via het internet) en cyberphysical systems (d.w.z. onderling geconnecteerde fysieke en digitale systemen die gecontrolleerd worden door computergebaseerde algoritmes) (Wollschlaeger, Sauter, \& Jasperneite, 2017). Beide systemische concepten helpen uiteindelijk fysieke machines 'intelligent' te maken. Meer bepaald worden machines in dergelijke omgeving gedreven door artifciële intelligentie - d.w.z. de machines bootsen menselijke cognitieve functies na zoals leren en het oplossen van problemen (Russell \& Norvig, 2009).

\subsection{Cobot-technologie}

Een specifieke soort intelligente machine die zal zorgen voor de cognitieve en fysieke ondersteuning van de menselijke operator in de industriële omgeving wordt de industriële collaboratieve robot (Gombolay, Gutierrez, Clarke, Sturla, \& Shah, 2015; Hold, Ranz, Sihn, \& Hummel, 2016). Dergelijke collaboratieve robots worden ook wel 'cobots' genoemd, zijn relatief goedkoop en makkelijk programmeerbaar, en kunnen op de werkplek van de operator zelf worden geïntegreerd, in tegenstelling tot traditionele robots die wegens veiligheidsredenen 
afgesloten in een beschermende veiligheidskooi actief zijn (Villani, Pini, Leali, \& Secchi, 2018). Op die manier worden ze gedefinieerd als robots die (letterlijk en figuurlijk) dichter bij de operator komen en deze in een coöperatieve omgeving helpen met erg complexe taken die niet geautomatiseerd kunnen worden (Ajoudani et al., 2018; Makrini, Merckaert, Lefeber, \& Vanderborght, 2017). De flexibiliteit, handigheid en het probleemoplossend vermogen van de menselijke operator wordt zo gecombineerd met de kracht, uithouding en precisie van robots (Bauer, Ollherr, \& Buss, 2008). Meer bepaald kan een cobot op basis van constante interactie met de operator via ondermeer geantropomorfiseerde signalen (Elprama, Makrini, Vanderborght, \& Jacobs, 2016) taken uitvoeren zoals het selecteren, aanbieden, lijmen of vastschroeven van assemblagestukken of het controleren van bijvoorbeeld foute positioneringen (Anandan, 2013; Villani et al., 2018).

\subsection{Cobotfunctionaliteiten en attitudes}

Cobots worden vooreerst ingezet om de productiviteit van de industriële productie te verhogen. Dit doen ze door bijvoorbeeld precisiewerk en denkwerk te verrichten of door het controleren van en wijzen op fouten (in de plaats van een leidinggevende) (vgl. Bogue, 2016; Elprama et al., 2017; Makrini et al., 2017). In de toekomst zouden cobots zelfs instructies kunnen geven, de autonomie kunnen bezitten een taak aan te vatten en als ondergeschikte kunnen fungeren van operatoren (vgl. Sauppé \& Mutlu, 2015). Ten tweede worden cobots ook ingezet om bijvoorbeeld repetititieve en gevaarlijke taken over te nemen, dit, om alomtegenwoordige musculoskeletale en psychosociale aandoeningen bij operatoren te vermijden (Akella et al., 1999; Elprama, Jewell, Jacobs, El Makrini, \& Vanderborght, 2017).

Bepaalde cobotfunctionaliteiten kunnen leiden tot positieve attitudes jegens cobots. Zo toonden Takayama en collega's (2008) aan dat mensen robots in het algemeen zelfs niet alleen zouden 
verkiezen voor de typische dangerous, dirty and dull taken, i.e., het uitvoeren van gevaarlijke, vuile en repetitieve taken (zie ook Elprama et al., 2017; Jacobs et al., 2019; TNS Opinion \& Social, 2015), maar ook voor dienstgerichte taken en taken die memorisatie en verfijnde perceptuele kunde vereisen. Elprama en collega's (2017) suggereren op hun beurt dat operatoren positief kunnen staan tegenover cobots die bijvoorbeeld assemblagecomponenten aangeven. Bovendien wordt gesuggereerd dat operatoren samenwerking met cobots kunnen prefereren als die adaptief is (bijv. Fletcher, Johnson, \& Larreina, 2019; Weiss \& Huber, 2016). Een voorbeeld hiervan die interesse geniet vanuit het werkveld is een cobot gestuurd door de mentale belasting van de operator (Landi et al., 2018) of de fysieke vermoeidheid van de operator (Peternel, Tsagarakis, Caldwell, \& Ajoudani, 2016), zodat bijvoorbeeld de mate waarin een cobot instructies geeft afgestemd is op de mate van mentale vermoedheid van de operator waarmee deze samenwerkt.

Andere cobotfunctionaliteiten kunnen dan weer leiden tot eerder negatieve attitudes. Dit door bijvoorbeeld het overnemen van (leidinggevende) taken door cobots (Gombolay et al., 2015) die zo de ervaren taakautonomie frustreren (vgl. Deci, Olafsen, \& Ryan, 2017; Złotowski, Yogeeswaran, \& Bartneck, 2017). Bovendien kunnen operatoren zich gaan frustreren aan cobots die te traag gaan (Elprama et al., 2017) of aan het gebrek aan de nodige flexibiliteit (vgl. Maurtua, Ibarguren, Kildal, Susperregi, \& Sierra, 2017) bij het anticiperen op onverwachte omstandigheden en nieuwe taken. Brougham en Haar (2018) observeerden zelfs dat robots voor minder werkplezier en tot meer cynisme kunnen leiden.

Bij uitbreiding lijkt ook de perceptie te groeien dat industriële cobots niet enkel taken, maar ook veel banen zullen overnemen (Jacobs, Tytgat, Maus, Meeusen, \& Vanderborght, 2019; verschillende studies lijken dit ook te voorspellen; Arntz, Gregory, \& Zierahn, 2016; Brynjolfsson, Mitchell, \& Rock, 2018). Specifiek denkt 70\% van de Europese burgers uit 
verschillende sectoren dat robots banen zullen overnemen - wat in lijn ligt met de opinie van een steekproef aan werknemers in de maakindustrie in Maurtua en collega's (2017) - terwijl één op drie respondenten aangeeft dat deze ook hun eigen job minstens deels kunnen overnemen (TNS Opinion \& Social, 2015). In België denkt meer dan de helft dat robots zijn of haar baan kunnen uitvoeren, terwijl twee op de drie zelfs de overtuiging heeft dat robots en artificiële intelligentie meer banen zullen doen verdwijnen dan creëren (Elprama et al., 2017; Jacobs et al., 2019). Gebaseerd op onderzoek naar prosociaal gedrag verkiezen mensen zelfs dat baanverlies bij andere werknemers opgevangen wordt door nieuwe werknemers in plaats van door robots (Granulo, Fuchs, \& Puntoni, 2019). Een kanttekening hierbij is wel dat dit effect omkeert wanneer men met potentieel persoonlijk baanverlies geconfronteerd wordt. Dit zou verklaard kunnen worden door een kleinere bedreiging voor het zelfbeeld in geval robots en niet nieuwe werknemers de eigen baan zouden overnemen (vgl. sociale vergelijkingstheorie, Festinger, 1954; Tesser, 1988).

\subsection{Doel studie}

Samengevat bijken robots en cobots zowel positieve als negatieve attitudes uit te lokken. In het licht van deze attitudes wordt op internationaal academisch vlak (bijv. McGaughey, 2018) en recent ook in de Vlaamse media daarom door experts het debat aangezwengeld over hoe de industrie kan omgaan met de bezorgdheden en opportuniteiten die deze onvermijdelijke technologische ontwikkeling met zich meebrengt (Jacobs et al., 2019; Maus, Vanderborght, Meeusen, \& Jacobs, 2018). Vooralsnog ontbreekt voldoende kennis over hoe industriële operatoren zich verhouden tot cobots en specifieke cobotfunctionaliteiten. Bedrijven, consultants en academici ontbreken op dit moment zo gecontextualiseerde en specifieke inzichten om de succesvolle implementatie van cobots te faciliteren. Eén van de redenen hiervoor is dat bovenstaand onderzoek voornamelijk bij de algemene bevolking werd 
uitgevoerd, waarbij de participanten bovendien een algemene beschrijving van robots aangeboden kregen. In realiteit zullen het echter operatoren zijn die in een concrete werkomgeving met een cobot met specifieke functionaliteiten zullen moeten werken. Het huidige onderzoek biedt zodoende ter ondersteuning van dit debat en deze implementatie een eerste verkenning bij operatoren in de assemblage-industrie en bij een gemakssteekproef van potentiële toekomstige operatoren.

\subsection{Overzicht studie}

Vandaag de dag hebben zeer weinig operatoren effectief reeds met een cobot samengewerkt. Evenmin hebben velen er gedegen kennis over. Een groot deel van de operatoren zal in de toekomst wel met deze technologie geconfronteerd worden. Het meten van cobot-acceptatie, i.e., een a posteriori pragmatische evaluatie van de technologie (Alexandre, Reynaud, Osiurak, \& Navarro, 2018), is dus nog niet mogelijk, daar er nog geen interactie met deze technologie heeft plaatsgevonden. Daarom focust de huidige studie zich op de accepteerbaarheid van cobots en cobotfunctionaliteiten, namelijk een a priori mentale representatie geconstrueerd vooraleer een interactie met de technologie heeft plaatsgevonden (Alexandre et al., 2018; Biassoni, Ruscio, \& Ciceri, 2016; Vlassenroot, Brookhuis, Marchau, \& Witlox, 2010). Meer specifiek richten we ons op de fase waarin de operator op basis van de informatie beschikbaar in de eigen en werkgerelateerde omgeving voor zichzelf de 'innovation-values fit' van cobots bepaalt (Alexandre et al., 2018; Biassoni et al., 2016; Rogers, 1995; Van Acker et al., 2020). De operator doet dit door het afwegen van deze informatie tegenover de persoonlijke waarden, d.w.z., de overtuigingen over de persoonlijke en sociale wenselijkheid van de voorgestelde technologie (Klein \& Sorra, 1996; zie ook Ajzen, 1991, 2001). Zo verkennen we de eerste mogelijke horde in het proces tot technologie-acceptatie. Naast de accepteerbaarheid zullen we ook specifiek de ervaren baanbedreiging meten. 
Voor deze studie vertrekken we vervolgens vanuit de volgende onderzoeksvragen: (1) wat is de ervaren baanbedreiging veroorzaakt door cobots, (2) wat is de functionaliteit-specifieke en algemene accepteerbaarheid van cobots en (3) is er een verschil in deze baanbedreiging en accepteerbaarheid tussen tewerkgestelde en toekomstige operatoren?

Daar deze studie een exploratie is binnen, specifiek, de assemblage-industrie selecteren we de meest centrale variabelen uit bovenstaande literatuur (Onderzoeksvraag 1 en Onderzoeksvraag 2; OV1 en OV2). Dit omdat we redeneren dat ervaren baanbedreiging en accepteerbaarheid anders wordt ingeschat bij operatoren in specifieke werkcontexten, in tegenstellling tot de eerdere bevragingen van de algemene bevolking op basis van algemene robotomschrijvingen. Zo voorzien we dat ervaren baanbedreiging en accepteerbaarheid zal verschillen in vergelijking met deze eerdere bevragingen omdat het toekomstig gebruik van cobots meer plausibel is voor beide groepen. We breiden hiermee bovendien het beperkte bestaande gecontextualiseerde onderzoek bij operatoren uit naar een meer omvattend onderzoek met substantieel grotere steekproef (vgl. Elprama et al. 2017).

Vervolgens onderzoeken we in welke mate huidige operatoren op deze variabelen verschillen van toekomstige operatoren (Onderzoeksvraag 3; OV3). Huidig tewerkgestelde operatoren kunnen namelijk een betere inschatting maken hoe een cobot diens werk zou kunnen beïnvloeden. Door het gebrek aan ervaring en kennis over een specifieke baancontext (zoals ook bestaat bij de algemene bevolking) maken toekomstige operatoren potentieel echter een minder gefundeerde inschatting over deze technologie. Door inzichten te verwerven bij beide groepen, kan deze studie zo bedrijven niet alleen helpen bij de implementatie van cobots bij bestaande werknemers, maar ook bij het recruteren en opleiden van nieuwe werknemers. 
Daar deze studie exploratief van aard is, kozen we ervoor om kwantitatieve methodes te combineren met kwalitatieve methodes. Meer bepaald gebruikten we een vragenlijst om de verschillende variabelen te meten, maar voorzagen we in deze vragenlijst ook voldoende open ruimte zodat de respondent bedenkingen en opinies kon formuleren die de vragen an sich niet maten. Daaropvolgend namen we met een deel van de operatoren de tijd om een semigestructureerd interview af te nemen waarin nog additioneel werd verkend naar mogelijke zorgen of interesses die de operatoren hadden bij mogelijke toekomstige samenwerking met cobots. Het combineren van beide methodes liet een inductieve en deductieve gegevensverzameling toe en voorzag dat deze elkaar verklarend zouden kunnen versterken.

\section{Methodologie}

\subsection{Participanten}

In totaal namen 83 participanten deel: 46 operatoren $\left(2\right.$ vrouwen, $M_{\text {Leeftijd }}=36.48, S D_{\text {Leeftijd }}=$ 12.13) uit twee Vlaamse maakbedrijven $\left(n_{1}=24, n_{2}=22\right)$ en 37 potentieel toekomstige operatoren $\left(4\right.$ vrouwen, $\left.M_{\text {Leeftijd }}=29.54, S D_{\text {Leeftijd }}=15.08\right)$ uit twee technische middelbare scholen en een opleiding tot lasser in het volwassenonderwijs.

Van de 46 operatoren kwam het merendeel $(n=38)$ uit het technisch onderwijs en beroepsonderwijs. Deze operatoren waren tewerkgesteld in een assemblageomgeving voor landbouwmachines en een assemblageomgeving voor weefgetouwen (met een gemiddelde ervaring binnen dezelfde baan binnen hetzelfde bedrijf van $M=13.32$ jaar, $S D=11.27$ jaar) waar de kans op toekomstig gebruik van cobots zeer reëel is. Beide bedrijven gaven aan dat cobots nog niet in de productieomgeving geïmplementeerd waren. Bij één bedrijf hadden sommige operatoren reeds een demonstratie met een cobot meegemaakt. 
Van de 37 potentieel toekomstige operatoren had het merendeel de lagere school $(n=17)$, technisch middelbaar $(n=7)$ en hogeschool $(n=11)$ als hoogst behaalde opleiding. Deze groep volgde een technische opleiding in verwarmingsinstallatietechnieken, elektromechanica en industriële wetenschappen of volgden een opleiding tot lasser - allemaal contexten waarin toekomstige samenwerking met cobots reëel is ( 20 mensen gaven aan geen werkervaring te hebben; 17 mensen gaven aan werkervaring te hebben binnen dezelfde baan binnen hetzelfde bedrijf met een gemiddelde van $M=16.29$ jaar, $S D=12.06$ jaar). Ook in deze subgroep had geen van de participanten reële werkervaring met cobots.

Uit de bevraging werd het gebrek aan kennis over cobots bij beide groepen bevestigd met een gemiddelde score van $M=2.81(S D=2.11)$ op de vraag of men wist wat een cobot was en met een sterke scheefheid (Skewness $=.73, S D=.27)$ en vlakheid $($ Kurtosis $=-.99, S D=.53)$ van de data (Kolmogorov-Smirnov normaliteitstest < .001) (gemeten op een 7-puntsschaal van 1 helemaal niet, tot 7 , helemaal wel). Ook vertoonden beide groepen een geringe mate aan ervaring met robots, met een gemiddelde score van $M=2.87(S D=1.82)$ op de vraag hoeveel ervaring men had in het samenwerken met robots en met een sterke scheefheid (Skewness $=.66$, $S D=.27$ ) en vlakheid (Kurtosis $=-.75, S D=.53$ ) van de data (Kolmogorov-Smirnov normaliteitstest $<.001)($ gemeten op een 7 -puntsschaal van 1 helemaal niet, tot 7, helemaal wel).

\subsection{Procedures}

In totaal was er voor het onderzoek een half uur beschikbaar per operator. Daarin werd een vragenlijst afgenomen en voor de operatoren eveneens een kort semi-gestructureerd interview. De onderzoekers gaven ook expliciet aan dat men gerust naast de vragen en op de daarvoor 
bestemde plaatsen meer informatie mocht opschrijven over de mening die de operator was toegedaan.

\subsubsection{Recrutering participanten}

Alle operatoren werden gerekruteerd door het bedrijf zelf, gebaseerd op onze vraag naar participanten met een zo groot mogelijke diversiteit in leeftijd, geslacht, werkervaring, al dan niet aangesloten bij een vakbond, mate aan voluntarisme, etc. Een belangrijk inclusiecriterium betrof het hebben van geen feitelijke (werk)ervaring met cobots. De groep van toekomstige operatoren werd gerecruteerd via de geselecteerde scholen.

\subsubsection{Toelichting studie}

Voor aanvang van het onderzoek werden de operatoren door de onderzoekers expliciet uitgelegd - zowel mondeling als in het formulier voor geïnformeerde toestemming - dat de vraag voor dit onderzoek vanuit de onderzoekers zelf kwam en de betrokken bedrijven hieraan hun medewerking verleenden via een gezamenlijk project. In deze studie, zo vertelden we, wilden we verkennen welke mening mensen op de werkvloer hebben over het samenwerken met de robots van de toekomst. Aan de toekomstige operatoren werd uitgelegd dat dit onderzoek werd uitgevoerd door een samenwerking van de bedrijven en de onderzoekers en dat de onderzoekers ook de mening van potentiële toekomstige operatoren wilden verkennen.

\subsubsection{Anonimiteit}

De operatoren werden individueel bevraagd in aan afgesloten ruimte binnen de fabriek waar ze tewerkgesteld waren. In deze afgesloten ruimtes waren enkel één of twee onderzoekers aanwezig terwijl inkijk onmogelijk was en ook gesprekken niet waarneembaar buiten de ruimtes - dit om te waarborgen dat de operatoren zich maximaal vrij voelden hun mening aan 
te geven. De toekomstige operatoren vulden de vragenlijst evenzeer individueel in, maar niet in een afgesloten ruimte, wegens praktische beperkingen.

Volledige anonimiteit van de data werd voor alle participanten gegarandeerd mondeling en met het geïnformeerde toestemmingsformulier. Het onderzoek en de gevolgde procedures werden door de bedrijven zelf voorgelegd aan en goedgekeurd door de vakbonden (die zelf niet betrokken waren in het verdere verloop van de studie).

\subsection{Materiaal}

De literatuur rond attitudes tegenover cobots is beperkt. Ook de tijd die we beschikbaar hadden voor het afnemen van de data per (toekomstige) operator was niet uitgebreid. Daarom werd een selectie gemaakt van variabelen afgeleid uit bovenstaande organizational change literatuur, de human-robot collaboration en technology acceptance literatuur. Alle variabelen werden vervolgens afgetoetst met experten in het domein (zijnde één innovatiemanager en één werkvoorbereider per betrokken bedrijf) op basis van wat zij op basis van hun ervaring inschatten als meest belanghebbend. De selectie en formulering van de vragenlijstitems gebeurde iteratief en op basis van samenwerking met het werkveld, overleg met domeinexperten en consultatie van beschikbare wetenschappelijke literatuur. Alle items werden bijgevoegd in Bijlage.

De vragenlijst werd als volgt gestructureerd. Eerst bevroegen we persoonsgerelateerde factoren en maten we de initiële ervaren baanbedreiging tegenover, in het algemeen, robots (d.w.z. de overkoepelende term, waarvan cobots een deel uitmaken) (zie Deel 1). Vervolgens kreeg men een beschrijving van industriële cobots te lezen (zie hieronder) en bevraagden we de accepteerbaarheid van specifieke cobotfunctionaliteiten (zie Deel 2). Tot slot polsten we naar de gepercipieerde baanbedreiging door cobots en de algemene accepteerbaarheid van cobots 
'Cobot accepteerbaarheid' (zie Deel 3). Een 7-puntsschaal (van 1 helemaal niet/zeer weinig tot 7 helemaal wel/zeer veel) werd gebruikt bij alle items.

\subsubsection{Vragenlijst Deel 1}

De volgende persoonsgerelateerde variabelen werden gemeten met één item per construct: leeftijd, huidge baanervaring, ervaring met robots en kennis over cobots. Aanvullend werd de persoonlijke technologische geletterdheid ('technology readiness') gemeten (Walczuch, Lemmink, \& Streukens, 2007; met een pragmatische 4-item schaal gebaseerd op Parasuraman, 2000; Victorino, Karniouchina, \& Verma, 2009) $(\alpha$ Operatoren $=.56, \alpha$ Toekomstige operatoren $=.62)$ wegens het mogelijke verband met de accepteerbaarheid van technologie en, specifiek, cobots (Bröhl, Nelles, Brandl, Mertens, \& Schlick, 2016). In dit eerste deel van de vragenlijst werd tot slot ook de gepercipieerde 'Aanvankelijke baanbedreiging' door, algemeen, robots gemeten, i.e., nog voor men een specifiek soort robot leerde kennen (Bröhl et al., 2016; Takayama, Ju, \& Nass, 2008; Złotowski et al., 2017),

\subsubsection{Vragenlijst Deel 2}

In lijn met de aangehaalde literatuur en volgend op de interesse van de bedrijven waarmee werd samengewerkt, en gegeven het gebrek aan reële (werk)ervaring met cobots bij de participanten, onderzochten we vervolgens hoe de operatoren zouden denken over mogelijke functionaliteiten van cobots, dit om een meer geïnformeerde inschatting te bekomen. Hiertoe kregen ze eerst twee foto's van cobots te zien samen met onderstaand neutraal omschreven vignette (gebaseerd op o.a. Bogue, 2016) over wat cobots zijn en voor wat die zoal ingeschakeld zouden kunnen worden, zodat iedere respondent op een gestandaardiseerde wijze kwam te weten wat een cobot is: 
"Een cobot kan geprogrammeerd worden om mee te werken in het uitvoeren van je job. Indien nodig, kan de cobot zo bijvoorbeeld componenten grijpen, ze roteren, de componenten aanbieden of ergens monteren. De cobot kan bijvoorbeeld ook herhalende taken uitvoeren of problemen oplossen indien die zich voor doen. Daarnaast kan de cobot ook fysiek zware taken uitvoeren of taken die veel precisie vragen. Door het gebruik van een camera kunnen sommige cobots herkennen of je klaar bent met een bepaalde taak en kun je met de cobot communiceren door bijvoorbeeld je duim naar de camera op te steken. Tot slot kan de cobot ook met jou communiceren om bijvoorbeeld instructies te tonen, om je aan iets te herinneren of je voor iets te waarschuwen."

Hieropvolgend werd de accepteerbaarheid van specifieke cobotfunctionaliteiten gemeten, d.w.z., in welke mate een cobot een bepaalde functionaliteit zou mogen bezitten in de veronderstelling dat de operator ooit zou samenwerken met een cobot (zoals geformuleerd in de instructies voor de participanten). We deden dit met 10 items gebaseerd op bovenstaande literatuur die met een exploratieve factoranalyse ${ }^{2}$ terug te leiden waren tot drie factoren. De eerste factor 'Fysieke functionaliteit' (Eigenwaarde $=4.38,43.83 \%$ verklaarde variantie, bestaande uit 4 items) omvatte een gemiddelde score over de vragen die de accepteerbaarheid maten van cobots die repetitieve taken zouden uitvoeren, fysiek zware taken, precisiewerk en die instructies zouden geven (bijv. 'Een cobot zou mij zaken zaken mogen vertellen om instructies overbodig te maken.'). 'Cognitieve functionaliteit' (Eigenwaarde $=1.30,13.05 \%$ verklaarde variantie, bestaande uit 3 items) was een gemiddelde score over de vragen die verkenden naar de accepteerbaarheid van cobots die veel denkwerk zouden uitvoeren, de leiding zouden nemen in de taakuitvoering en de autonomie zouden hebben om een taak aan te vatten (bijv. 'Een cobot zou zelf mogen beslissen om aan een taak te beginnen.'). De derde factor 'Kwaliteitsfunctionaliteit' $($ Eigenwaarde $=1.03,10.26 \%$ verklaarde variantie, bestaande uit 3 
items) was een gemiddelde score over de vragen die de accepteerbaarheid maten van cobots die zouden controleren op fouten, op fouten zouden wijzen in plaats van een overste en als ondergeschikte van operatoren zouden fungeren (bijv. 'Ik zou het leuk vinden om enkele cobots voor mij te laten werken.').

Vervolgens maten we met 6 items de accepteerbaarheid van adaptieve cobotfunctionaliteiten. Adaptief maten we hier als cobotfunctionaliteiten die zich zouden aanpassen aan de mentale vermoeidheid van de operator gemeten op basis van videobeelden. Een exploratieve factoranalyse leidde tot één factor 'Adaptieve functionaliteit' (Eigenwaarde $=3.17,52.89 \%$ verklaarde variantie) die een gemiddelde vertegenwoordigde van de accepteerbaarheidscores op een cobot die taken zou over nemen, het werktempo aanpassen, het werk meer of minder controleren op fouten, meer of minder instructies zou geven, de operator zou waarschuwen om iets aan de vermoeidheid te doen en of men daadwerkelijk vertrouwen zou hebben in dergelijke behandeling van gegevens door cobots (bijv. '... mij vervolgens te waarschuwen zodat ik zelf kan beslissen iets aan de mentale vermoeidheid te doen.').

\subsubsection{Vragenlijst Deel 3}

De vragenlijst werd afgesloten met drie algemene vragen. De inleiding van deze vragen stelde dat de participant nu, door de eerder gelezen cobotomschrijving en het beantwoorden van alle vragen omtrent specifieke cobotfunctionaliteiten, een beter en meer volledig beeld had gekregen van wat cobots zijn en wat ze kunnen. Vervolgens bevraagden we (elk met één item en in het geval de cobot volledig zou voldoen aan de wensen van de operator) in welke mate de operator vond dat de beschreven cobot zou kunnen helpen in de baan ('Indien zo'n cobot volledig zou voldoen aan jouw wensen, in welke mate denk je dat deze cobot je zou kunnen helpen in je job?', gebaseerd op 'perceived usefulness', Davis, 1989; Venkatesh et al., 2016), de 
cobot een bedreiging zou vormen voor het behouden van de baan (als variabele benoemd als 'Uiteindelijke baanbedreiging'; 'Indien zo'n cobot volledig zou voldoen aan jouw wensen, in welke mate zou je deze cobot een bedreiging vinden voor het behouden van je job?', vgl. Jacobs et al., 2019) en in welke mate men zou willen samenwerken met zo'n cobot ('Indien zo'n cobot volledig zou voldoen aan jouw wensen, in welke mate zou je met deze cobot willen samenwerken?', gebaseerd op de 'intention to use', Venkatesh et al., 2016; in relatie tot cobots, zie Bröhl et al., 2016). De vraag naar gepercipieerd nut en de vraag naar intentie tot gebruik bleken vervolgens sterk te correleren $(r=.68, p<.01)$, zodat we een gemiddelde score voor beiden berekenden en de nieuwe variabele 'Cobot accepteerbaarheid' gebruikten voor de analyses.

\subsubsection{Open vragen en semi-gestructureerd interview}

Bij verschillende items uit de vragenlijst was tot slot ook ruimte voorzien om dieper in te gaan op de mening die de participanten via de Likert-schaal hadden aangegeven. Bij de operatoren werd door $n=33$ één of meerdere opmerkingen gegeven bij deze open vragen, bij de toekomstige operatoren was $\operatorname{dit} n=28$.

Na de vragenlijst werd, waar mogelijk binnen het tijdsbestek, bij 27 van de 46 operatoren finaal een semi-gestructureerd interview afgenomen. Daarin werd eerst zeer algemeen gevraagd wat de operator in het algemeen dacht van cobots. Vervolgens werd specifieker gevraagd waarom de operator een samenwerking met cobots al dan niet een goed idee zou vinden. Bij deze tweede vraag werd de operator aangemoedigd voorbeelden te geven van cobotfunctionaliteiten die voor hem of haar hierin doorslaggevend zouden zijn. Een derde vraag verkende de accepteerbaarheid van een cobot die met behulp van een camera de mentale belasting zou kunnen meten. Het semi-gestructureerd interview werd niet afgenomen bij de toekomstige operatoren wegens 
organisatorische overwegingen (zo konden de studenten o.a. niet afzonderlijk in een afgesloten ruimte worden bevraagd en was ook de beschikbare tijd te beperkt).

De kwalitatieve data van het interview werd samengevoegd met de data van de open vragen en werd door één onderzoeker geanalyseerd door middel van thematische analyse met behulp van het nVivo software pakket (QSR, 2018). Het ontwikkelen van het codeerschema gebeurde in iteratieve fases (zie, Nowell, Norris, White, \& Moules, 2017) en volgde onder meer de valentiestructuur van de accepteerbaarheid van cobotfunctionaliteiten, cobots algemeen en cobots in verhouding tot baanbedreiging (in lijn met de thematische analyse in Brougham \& Haar, 2018). Zo kwam bijvoorbeeld één thema naar voren dat de algemene accepteerbaarheid van cobots representeerde, met daaronder als subthema's meningen ten voordele van cobots, neutrale meningen, negatieve meningen, voorwaardelijke meningen en meningen over de onvermijdelijkheid van cobots.

\section{Resultaten}

\subsection{Ervaren baanbedreiging}

De ervaren baanbedreiging werd voor beide deelsteekproeven op twee momenten binnen onze vragenlijst gemeten: voor de participanten enige informatie kregen over wat cobots zijn ('Aanvankelijke baanbedreiging') en op het einde van de vragenlijst nadat ze kennis hadden gemaakt met cobots ('Uiteindelijke baanbedreiging').

Een MANOVA toonde aan dat de scores op de twee momenten significant van elkaar verschilden, Wilks' Lambda $=.79, F(1,77)=19.98, p<.001$, partial eta-squared $=.21$ en dat de operatoren significant verschilden van de niet-operatoren, $F(1,77)=17.66, p<.05$, partial eta-squared $=.05$. Een interactie-effect tussen het moment waarop de baanbedreiging werd 
gemeten en de baanstatus (operator vs. toekomstige operator) werd niet gevonden, Wilks' Lambda $=.98, F(1,77)=1.95 p=.17$, partial eta-squared $=.03$.

Meer bepaald schatten de operatoren de ervaren Aanvankelijke baanbedreiging gemiddeld tot laag in $(M=3.41, S D=1.54$; zie, alle variabelen gemeten op een 7-puntsschaal $)$, terwijl de toekomstige operatoren hier laag op scoorden $(M=2.46, S D=1.54)$. De ervaren Uiteindelijke baanbedreiging werd vervolgens voor de operatoren volledig neutraal $(M=4.02, S D=1.69)$. Voor de toekomstige operatoren werd dit neutraal tot laag $(M=3.63, S D=.88)$.

Kortom, nadat men kennis heeft genomen over wat cobots zijn, blijkt de ervaren baanbedreiging significant te stijgen in beide deelsteekproeven. De operatoren ervaren een eerder gemiddelde baanbedreiging en de toekomstige operatoren een eerder lage baanbedreiging.

\subsection{Accepteerbaarheid cobotfunctionaliteiten}

Vooreerst stonden de operatoren positief ten aanzien van Fysieke functionaliteiten $(M=5.80$, $S D=0.81$, waarvan de score significant hoger lag dan de toekomstige operatoren die er niettemin evenzeer positief tegenover stonden $(M=5.20, S D=1.16), t=-2.78, p<.01$, zie Tabel 1). Tegenover Cognitieve functionaliteiten stonden de operatoren neutraal $(M=4.29, S D$ $=1.17$, wat significant hoger is dan de neutrale tot lage inschatting van de toekomstige operatoren $(M=3.42, S D=1.44), t=-3.05, p<.01$. De Kwaliteitsfunctionaliteit werd positief ingeschat door de operatoren $(M=5.28, S D=1.14)$, tevens significant hoger dan de neutrale score van de toekomstige operatoren $(M=4.18, S D=1.34), t=-4.05, p<.001$. Ten vierde stonden zowel de operatoren $(M=4.38, S D=1.16)$ als de toekomstige operatoren $(M=4.24$, $S D=1.26)$ neutraal en niet significant verschillend van elkaar tegenover de Adaptieve functionaliteit, $t=-0.50, p=.62$. 
Een one-way repeated measures ANOVA toonde aan dat voor de operatoren alle accepteerbaarheidsscores voor de functionaliteiten significant verschillen van elkaar (alle $p \mathrm{~s}<$ .01), met uitzondering van het verschil tussen de Cognitieve en Adaptieve functionaliteit, Wilks' Lambda $=.26, F(3,43)=39.89, p<.001$, partial eta-squared $=.74$. Voor de toekomstige operatoren verschillen alle accepteerbaarheidsscores voor de functionaliteiten significant van elkaar (alle $p$ s $<.05$ ), met uitzondering van het verschil tussen de Kwaliteitsfunctionaliteit en de Adaptieve functionaliteit, Wilks' Lambda $=.31, F(3,43)=25.81, p<.001$, partial etasquared $=.70$.

Samengevat scoort voor de operatoren de accepteerbaarheid van vooral de fysieke en kwaliteitsfunctionalitet wat hoger dan gemiddeld, terwijl de cognitieve en adaptieve functionaliteit neutraal uitvalt. De toekomstige operatoren scoren significant lager voor alle functionaliteiten met uitzondering van de adaptieve, terwijl de fysieke functionaliteit hoger, en de cognitieve functionaliteit lager dan gemiddeld wordt ingeschat op accepteerbaarheid.

\subsection{Accepteerbaarheid cobots algemeen}

De operatoren schatten vervolgens de algemene Cobot accepteerbaarheid eerder positief in $(M$ $=4.97, S D=1.30$ ), wat significant hoger bleek dan de neutrale inschatting van de toekomstige operatoren $(M=4.28, S D=1.60), t=-2.15, p<.05($ zie Tabel 1$)$.

Tabel 1: Descriptieve resultaten studievariabelen en verschillen tussen operatoren en toekomstige operatoren in relatie tot respectieve onderzoekvragen (OV1, OV2 en OV3)

\begin{tabular}{|c|c|c|c|c|c|c|}
\hline & \multicolumn{2}{|c|}{ Operatoren } & \multicolumn{2}{|c|}{$\begin{array}{c}\text { Toekomstige } \\
\text { operatoren }\end{array}$} & & \multirow{2}{*}{$\begin{array}{c}\text { (OV } \\
3) \\
p\end{array}$} \\
\hline Baanbedreiging (OV1) & $M$ & $S D$ & $M$ & $S D$ & $t$ & \\
\hline $\begin{array}{l}\text { Aanvankelijke baanbedreiging } \\
\text { door robots }\end{array}$ & 3.41 & 1.51 & 2.46 & 1.54 & & \\
\hline
\end{tabular}




\begin{tabular}{l|ccccccc}
$\begin{array}{l}\text { Uiteindelijke baanbedreiging } \\
\text { door cobots }\end{array}$ & 4.02 & 1.69 & 3.63 & 1.88 & & \\
& & & & & & \\
$\begin{array}{l}\text { Accepteerbaarheid cobotfunctionaliteiten } \\
\text { (OV2) }\end{array}$ & & & & & & \\
Fysiek & 5.80 & 0.81 & 5.20 & 1.16 & -2.78 & $<.01$ \\
Cognitief & 4.29 & 1.17 & 3.42 & 1.44 & -3.05 & $<.01$ \\
Kwaliteit & 5.28 & 1.14 & 4.18 & 1.34 & -4.05 & $<$ \\
& & & & & & .001 \\
Adaptief & 4.38 & 1.16 & 4.24 & 1.26 & -0.50 & .62 \\
& & & & & & \\
Cobot accepteerbaarheid (algemeen) & 4.97 & 1.30 & 4.28 & 1.60 & -2.15 & $<.05$ \\
(OV2) & & & & & & \\
\hline
\end{tabular}

NB: alle $p$ s tweezijdig getoetst

\subsection{Associaties tussen de studievariabelen}

Vervolgens verkenden we de associaties tussen alle variabelen opgenomen in onze vragenlijst.

We werkten hiermee met de totale steekproef van zowel operatoren als toekomstige operatoren die we samenvoegden tot $N=83$. Tabel 2 geeft een overzicht van de gemiddeldes, standaardeviaties en de correlaties. We zien vooreerst een matig positieve samenhang tussen Aanvankelijke en Uiteindelijke baanbedreiging. Daarnaast vonden we een matige positieve samenhang tussen de accepteerbaarheid van de cobofunctionaliteiten onderling en tussen de functionaliteiten en Cobot accepteerbaarheid.

Van onze persoonsgerelateerde variabelen zien we een matige positieve samenhang tussen leeftijd en de fysieke cobotfunctionaliteit. Technologische geletterdheid, toont interessant genoeg een zwak positief verband met de accepteerbaarheid van alle cobofunctionaliteiten en cobot accepteerbaarheid. De correlaties voor de baanstatus (d.w.z., operator vs. toekomstige operator) bevestigen (logischerwijs) de verschillen zoals samengevat in Tabel 1 en tonen ook dat operatoren hoger scoren op technologische geletterdheid. 
Tabel 2: Descriptieve resultaten en Pearson zero-order correlaties tussen studievariabelen

$(N=83)$

\begin{tabular}{|c|c|c|c|c|c|c|c|c|c|c|c|c|}
\hline Variabelen & $M$ & $S D$ & 1 & 2 & 3 & 4 & 5 & 6 & 7 & 8 & 9 & 10 \\
\hline $\begin{array}{l}\text { 1. Aanvankelijke } \\
\text { baanbedreiging } \\
\text { (robots) }\end{array}$ & 3.00 & 1.59 & & & & & & & & & & \\
\hline $\begin{array}{l}\text { 2. Uiteindelijke } \\
\text { baanbedreiging } \\
\text { (cobots) }\end{array}$ & 3.93 & 1.82 & $.45^{* *}$ & & & & & & & & & \\
\hline 3. Fysiek & 5.54 & 1.02 & .04 & -.05 & & & & & & & & \\
\hline 4. Cognitief & 3.90 & 1.36 & .19 & -.01 & $.52 * *$ & & & & & & & \\
\hline 5. Kwaliteit & 4.79 & 1.34 & .02 & .01 & $.60^{* *}$ & $.46^{* *}$ & & & & & & \\
\hline 6. Adaptief & 4.12 & 1.20 & -.08 & -.14 & $.42 * *$ & $.53^{* *}$ & $.55^{* *}$ & & & & & \\
\hline $\begin{array}{l}\text { 7.Cobot } \\
\text { accepteer- } \\
\text { baarheid }\end{array}$ & 4.66 & 1.48 & -.06 & .10 & $.49^{* *}$ & $.49^{* *}$ & $.62 * *$ & $.52 * *$ & & & & \\
\hline 8. Leeftijd & 33.39 & 13.88 & -.02 & -.05 & $.35^{* *}$ & .05 & .08 & -.01 & .08 & & & \\
\hline $\begin{array}{l}\text { 9. Technolo- } \\
\text { gische } \\
\text { geletterdheid }\end{array}$ & 4.24 & 1.14 & .16 & .05 & $.22 *$ & $.30^{* *}$ & $.33^{* *}$ & $.22 *$ & $.38 * *$ & -.10 & & \\
\hline 10. Baanstatus & .55 & .50 & $.30^{* *}$ & .06 & $.30^{* *}$ & $.32 * *$ & $.41 * *$ & .06 & $.23 *$ & $.25^{*}$ & $.26^{*}$ & \\
\hline
\end{tabular}

Om te verkennen in welke mate onze studievariabelen de Cobot accepteerbaarheid voorspellen, voerden we een exploratieve regressie-analyse uit met de vier cobotfunctionaliteiten en de drie persoonsgerelateerde variabelen, leeftijd en technologische geletterdheid als predictoren (werkervaring werd niet opgenomen omdat niet iedereen hieraan voldeed) en Cobot accepteerbaarheid als afhankelijke variabele. Opnieuw werkten we met de totale $N=83$.

Het model was statistisch significant, $F(4,74)=10.30, p<.001$. Enkel de Kwaliteitsfunctionaliteit bleek een significant effect te hebben $($ beta $=0.39, p<.01)$ (zie Tabel 3). In tegenstelling tot de correlatieanlayses zien we geen significant effect van technologische geletterdheid, wat te wijten kan zijn aan de te kleine statistische power. Bij deze regressieanalyse hebben we namelijk een wat beperkte steekproefgrootte voor het aantal predictoren (zie, Tabachnick \& Fidell, 2013, die een $N>50+8 m$ vooropstellen, waarbij ' $m$ ' het aantal onafhankelijke variabelen is). Eenzelfde regressiemodel met Uiteindelijke baanbedreiging als afhankelijke variabele bleek niet significant (zie tabel 4). 
Tabel 3: Resultaten van de Multiple Regressie Analyse voor Cobot accepteerbaarheid $(N=$ 83)

\begin{tabular}{lccc} 
Variabelen & $\boldsymbol{t}$ & $\boldsymbol{p}$ & Beta \\
\hline $\begin{array}{l}\text { Cobotfunctionalitei } \\
\text { ten }\end{array}$ & & & \\
Fysiek & .71 & .48 & .09 \\
Cognitief & 1.39 & .17 & .16 \\
Kwaliteit & 3.09 & $<.01$ & .39 \\
Adaptief & 1.39 & .17 & .16 \\
& & & \\
Persoonsvariabelen & & & \\
Leeftijd & -1.28 & .21 & -.12 \\
Technologische & 1.65 & .10 & .15 \\
geletterdheid & & & .004 \\
Baanstatus & .05 & .97 & \\
\hline NB. & &
\end{tabular}

NB. Met Cobot accepteerbaarheid als afhankelijke variabele

Tabel 4: Resultaten van de Multiple Regressie Analyse voor Uiteindelijke baanbedreiging ( $N$ $=83)$

\begin{tabular}{lccc} 
Variabelen & $\boldsymbol{t}$ & $\boldsymbol{p}$ & Beta \\
\hline Cobotfunctionaliteit & & & \\
en & & & \\
Fysiek & -.36 & .72 & -.06 \\
Cognitief & .61 & .54 & .10 \\
Kwaliteit & .76 & .45 & .13 \\
Adaptief & -1.53 & .13 & -.24 \\
& & & \\
Persoonsvariabelen & & & -.06 \\
Leeftijd & -.44 & .66 & -.03 \\
Technologische & -.25 & .80 & .02 \\
geletterdheid & & & \\
Baanstatus & .17 & .87 & \\
\hline NB. Met Uiteindelijke baanbedreiging als afhankelijke variabele &
\end{tabular}

Alles samen blijken de cobotfunctionaliteiten onderling positief samen te hangen en op hun beurt met Cobot accepteerbaarheid, terwijl ook Technologische geletterdheid met al deze cobotvariabelen positief samenhangt. Leeftijd blijkt ook positief samen te hangen met een 
voorkeur voor de Fysieke functionaliteit. Kwaliteitsfunctionaliteit, ten slotte, blijkt de enige voorspeller van Cobot accepteerbaarheid.

\subsection{Thematische analyse}

Ervaren baanbedreiging

Op basis van een thematische analyse van de antwoorden op de open vragen en het semigestructureerd interview (samengevat in Tabel 5) benadrukten sommige operatoren dat cobots er onder andere voor zullen zorgen dat er minder banen zijn, dat cobots ook nooit ziek zijn of nooit moeten rusten en zo het bedrijf winstgevender kunnen maken ten nadele van operatoren. Verschillende operatoren zijn dan ook bang dat toekomstige generaties, van vooral lager opgeleide mensen, inderdaad zullen moeten vrezen voor hun baan (dergelijke meningen werden 12 keer venoemd, d.w.z. $n_{\text {vernoemd }}=12$ ). Meerdere operatoren waren enkel voorzichtig en wezen op bepaalde voorwaarden bij een mogelijke implementatie, bijvoorbeeld dat cobots niet te veel capaciteiten zouden mogen bezitten $\left(n_{\text {vernoemd }}=4\right)$

Toch gaven meerdere operatoren aan dat cobots niet alle competenties zullen hebben die een operator bezit waardoor ze niet zo bang zijn hun baan te verliezen $\left(n_{\text {vernoemd }}=17\right)$. Naast het garanderen van de betrouwbaarheid wordt namelijk ook, o.a., probleemoplossend vermogen en de organisatie van taakuitvoering gezien als iets wat enkel operatoren kunnen. Ter illustratie:

"Er zal altijd wel menselijke 'know-how' nodig zijn om alles goed te laten verlopen." (operator A)

"Het is te zien voor welke stukken en welke robot het is. Je gaat altijd een operator nodig hebben." (operator B) 
Specifiek met betrekking tot de cobotfunctionaliteiten kwam naar voren dat sommige operatoren een cobot als een voordeel zouden zien $\left(n_{\text {vernoemd }}=45\right)$ bij het herkennen en grijpen van de juiste assemblagecomponenten of door de operator te wijzen op zaken die hij/zij zou vergeten. Ook cobots die op veiliger gedrag wijzen, die operatoren in opleiding begeleiden en die het werk werkbaar maken voor oudere werknemers werd opgeworpen als een interessante piste.

Bij de vragen omtrent het inzetten van adaptieve cobots die, op basis van videobeelden, de mentale vermoeidheid van een operator zou kunnen inschatten, waren verschillende operatoren wat voorzichtig in hun oordeel $\left(n_{\text {vernoemd }}=18\right)$. Zo brachten sommige operatoren het argument aan dat het systeem niet zou mogen weten hoe je je voelt, dat operatoren geen machines mogen worden en dat de input niet gebruikt zou mogen worden om mensen te ontslaan. De data zouden dan ook niet verder dan de cobot mogen gaan, of maximaal toegankelijk voor de bedrijfsarts en enkel op geaggregeerd niveau beschikbaar voor het management. Nog andere operatoren prefereerden enkel periodieke in plaats van continue metingen van de mentale vermoeidheid, zoals bijvoorbeeld bij trainingsessies. Privacy was dus sowieso een bezorgdheid. Andere participanten steunden dit idee veeleer $\left(n_{\text {vernoemd }}=11\right)$ en hadden zelfs geen probleem dat een cobot hun mentale vermoeidheid constant monitort. Dergelijke metingen zouden volgens een operator zelfs kunnen helpen tegen burnout, omdat sommige operatoren niet zomaar hun overste vertellen hoe ze zich voelen. We citeren:

"Je wordt beoordeeld op iets dat je zelf niet altijd toe wil geven of laten blijken. Soms kan het misschien wel handig zijn." (operator C)

"Er wordt altijd het uiterste geëist van een arbeider, productie gaat voor mentale vermoeidheid." (operator D) 
Volgens operator E zou het systeem (d.w.z. adaptieve cobot) net kunnen bewijzen aan het management hoe hoog mentaal belast operatoren soms zijn. Tot slot hadden verschillende operatoren $\left(n_{\text {vernoemd }}=11\right)$ vragen bij de betrouwbaarheid van mentale vermoeidheidsmetingen door cobots, aangezien deze gevoelig kunnen zijn aan dagelijkse variatie, interpersoonlijke verschillen in bijvoorbeeld fysiologie en persoonlijke stressniveau's.

\section{Accepteerbaarheid cobots algemeen}

In termen van Cobot accepteerbaarheid gaf de thematische analyse aan dat sommige operatoren cobots als een onvermijdbare evolutie zien, omdat we bijvoorbeeld mee moeten met onze tijd $\left(n_{\text {vernoemd }}=5\right)$. Sommigen zien het als een positieve evolutie $\left(n_{\text {vernoemd }}=10\right)$, anderen zijn erg voorzichtig en wijzen op de nodige voorwaarden $\left(n_{\text {vernoemd }}=9\right)$, bijvoorbeeld omwille van veiligheidsredenen ("Omdat routine nodig is voor de veiligheid."). Aan de negatieve kant $\left(n_{\text {vernoemd }}=14\right)$ waren enkele operatoren bezorgd dat cobots hun werk zouden vertragen door de vereiste stappen en procedures. Interessant genoeg werd ook het gebrek aan menselijk contact en de uitsluiting van sommige groepen mensen als een bezorgdheid aangehaald en één operator gaf aan dat operatoren ook lui zouden kunnen worden door het samenwerken met een cobot. Verder gaven meerdere operatoren aan hun twijfels te hebben over de betrouwbaarheid van de acties en taken die de cobot zou uitvoeren $\left(n_{\text {vernoemd }}=5\right)$. Zou een cobot altijd fouten ontdekken? Kan het detecteren dat de schroefdraad beschadigd is? Volgende quote illustreert deze bezorgdheden:

"Ik wil misschien niet de totale afhankelijkheid van cobots omdat de tolerantie van afwerking soms niet klopt, menselijke tussenkomst blijft dan handig." (operator F)

\section{Toekomstige operatoren}

Het aantal keer de thema's voorkwamen binnen de data van de potentieel toekomstige operatoren lag wat anders, maar kende dan ook een kleinere steekproef daar geen interview 
werd afgenomen. Interessant was dat één respondent hier aangaf dat de cobot-evolutie een positieve evolutie betekent omdat dit ook nieuwe jobs kan creëren (zoals "reparatie, installatie, programmeren"), terwijl meerdere respondenten ook wezen op het voordeel van adaptieve cobots voor de veiligheid. De resultaten van deze thematische analyse worden weergegeven in Tabel 5.

Tabel 5: Samenvatting van thematische analyse met aantal keer een subthema werd vernoemd voor beide steekproeven

\begin{tabular}{lcc}
\hline & $\begin{array}{c}\text { Operatoren } \\
(\boldsymbol{n}=\mathbf{3 3})\end{array}$ & $\begin{array}{c}\text { Toekomstige } \\
\text { operatoren } \\
(\boldsymbol{n}=\mathbf{2 8})\end{array}$ \\
\cline { 2 - 3 } Thema (en voorbeelden) & $\boldsymbol{n}_{\text {vernoemd }}$ & $\boldsymbol{n}_{\text {vernoemd }}$ \\
\hline $\begin{array}{c}\text { 1. Ervaren baanbedreiging } \\
\text { c) Operator altijd nodig } \\
\text { "Cobot zal nog geprogrammeerd moeten } \\
\begin{array}{l}\text { worden" } \\
\text { b) Voorzichtigheid }\end{array}\end{array}$ & 17 \\
$\begin{array}{l}\text { "Ze mogen niet teveel kunnen" } \\
\text { a) Operator wordt redundant } \\
\text { "Cobots zijn nooit ziek" }\end{array}$ & 4 & 2 \\
\end{tabular}

\section{Accepteerbaarheid cobotfunctionaliteiten}

a) Positieve suggesties

"Automatisch herkennen en aanbieden van componenten"

b) Steun adaptieve cobot

"Goed tegen burnout"

d) Voorzichtigheid privacy en einddoel adaptieve cobot

"Niet om mensen te ontslaan"

c) Twijfel betrouwbaarheid adaptieve

cobot

"De ene dag is de andere niet"

\section{Accepteerbaarheid cobots algemeen}

a) Onvermijdelijke evolutie

"Je kan het niet tegenhouden"

b) Positieve evolutie 
"Om het werk te verlichten"

c) Voorzichtigheid

"Wat als cobot tempo wil bepalen"

d) Negatieve evolutie

"Mensen zullen lui worden"

e) Twijfel betrouwbaarheid cobot

"Cobot kan niet zien als iets fout is"

\section{Discussie}

Aansluitend bij de huidige technologische ontwikkelingen en de toenemende feitelijke haalbaarheid om cobots in te zetten in het bedrijfsleven beoogde deze studie een verkenning van de ervaren baanbedreiging door cobots (Onderzoeksvraag 1), de accepteerbaarheid van cobotfunctionaliteiten en cobots algemeen (Onderzoeksvraag 2) en hoe huidige en toekomstige operatoren verschillen op deze variabelen (Onderzoeksvraag 3). Met deze ervaren baanbedreiging en accepteerbaarheid focusten we op de cruciale initiële fase van acceptatie, d.w.z. nog voor er interactie met de nieuwe technologie - hier een cobot- heeft plaatsgevonden. De bevraagde steekproef bood een grote mate aan ecologische validiteit, daar de participerende operatoren effectief in een productieomgeving werkten waar de kans groot is dat cobots in de toekomst hun intrede zullen maken.

\subsection{Verworven inzichten}

\section{Baanbedreiging door cobots}

Met betrekking tot de ervaren baanbedreiging (vgl. OV1) stellen we algemeen vast dat zowel actueel tewerkgestelde als toekomstige operatoren (vgl. OV3) een beperkt niveau van baanbedreiging rapporteerden ten gevolge van, respectievelijk, robots in het algemeen en cobots specifiek. Dit is een opmerkelijke bevinding omdat eerder onderzoek aantoont dat de algemene populatie in België en Europa ervaart dat robots banen overnemen, een substantieel deel hiervan denkt dat een robot hun eigen baan kan overnemen (Jacobs et al., 2019; TNS Opinion \& Social, 2015), werknemers in de maakindustrie geloofden dat robots banenverlies 
zullen veroorzaken (Maurtua et al., 2017) en een kleine steekproef aan operatoren in de maakindustrie baanbedreiging ervaarde na interactie met een cobot (Elprama et al., 2017).

Vergelijkende subgroepanalyse geeft een preciezer beeld. Zo ervaarde de groep actueel tewerkgestelde operatoren, in vergelijking met de groep van toekomstige operatoren, gemiddeld genomen een statistisch significant grotere aanvankelijke baanbedreiging ten gevolge van robots. Beide groepen vertoonden dan weer geen statistisch significant verschillende ervaren baanbedreiging ten gevolge van de implementatie van cobots. Daarnaast steeg de bij het begin van de vragenlijst ervaren aanvankelijke baanbedreiging door robots van laag (voor de toekomstige operatoren) en eerder lager dan gemiddeld (voor de operatoren) naar een neutrale score naarmate de participanten meer leerden over cobots (een meer specifiek type robot) door het invullen van de vragenlijst en het lezen van de aangeboden cobotbeschrijving.

De bevinding dat de scores eerder laag en neutraal uitvallen suggereert dat (toekomstige) operatoren mogelijk positieve mogelijkheden of functionaliteiten verwachten van of associëreren met cobots in het algemeen. Interessant genoeg suggereert onze thematische analyse aan de andere kant dat de operatoren de betrouwbaarheid en capaciteiten van cobots eerder laag inschatten. Meerdere operatoren zijn van mening dat een menselijke factor steeds nodig zal blijven, vandaar mogelijks de eerder lage tot gemiddelde score. Op deze manier biedt de kwalitatieve data een sterke verklarende toegevoegde waarde aan de kwantitatieve data en nodigen deze resultaten uit tot toekomstig nog meer geavanceerd kwalitatief onderzoek waarin bijvoorbeeld user-centered design methodieken (Gould \& Lewis, 1985; Hoecherl, Schmargendorf, Wrede, \& Schlegl, 2018) worden toegepast. Zo kan nog een extra stap worden gezet in de opeenvolging van het eerdere algemene attitudinaal onderzoek bij de algemene bevolking, naar het huidige meer gecontextualiseerde onderzoek, naar uiteindelijk 
doorgedreven gecontextualiseerd opinie-onderzoek die de rijke werkomgeving en persoonlijke motivaties onderzoekt op het niveau van werknemer, team en organisatie.

Voorgaand onderzoek presenteerde al dan niet een algemene omschrijving van robots en stelde vervolgens de vraag naar de ervaren aanvankelijke baanbedreiging door robots. In de huidige studie veronderstelden we dat de accepteerbaarheid en de ervaren baanbedreiging door robots anders kan zijn na kennismaking met specifieke functionaliteiten van cobots. We verkenden daarom het potentiële verschil tussen de aanvankelijke ervaren bedreiging door robots (op basis van een algemene indruk bij de respondenen, zonder uitleg over robots) en de uiteindelijke ervaren baanbedreiging door cobots na kennismaking met cobotfunctionaliteiten. Bij de eerste vraag wilden we dus vooreest zien hoe voorgaand onderzoek over robots in het algemeen (die een algemene indruk meet bij respondenten gebaseerd op informatie verworven van bijv. media en collega's) repliceerde in onze steekproef. Vergelijkend met de tweede vraag verkenden we vervolgens hoe een grondigere kennis over cobots specifiek (als een type robot met potentieel meer baanrelevantie voor de participant; zie de invloed van baanrelevantie op acceptatie in Venkatesh \& Davis, 2000) en specifieke cobotfunctionaliteiten de ervaren baanbedreiging kan beïnvloeden. Dit bleek wel degelijk een effect te hebben.

De bevinding dat de scores stegen naarmate de participanten meer leerden over cobots dooheen de vragenlijst is een opmerkelijke bevinding gezien acceptatie of adoptie van technologie net kan verhogen door effectieve interactie met een nieuwe technologie (Venkatesh et al., 2016). Hier blijkt dus dat deze interactie potentieel ook een tegengesteld effect zou kunnen veroorzaken. Het feit dat de scores op ervaren uiteindelijke baanbedreiging nog steeds neutraal waren (d.w.z. niet positief werden) zou kunnen aangeven dat door het leren kennen van de cobotfunctionaliteiten men tegelijk (nog steeds) de indruk kreeg dat de cobotfunctionaliteiten niet erg betrouwbaar, noch volledig implementeerbaar zijn in de bedrijfspraktijk; waardoor 
operatoren hun initieel skepticimse niet substantieel veranderde. Deze kleine stijging in de gepercipieerde baanbedreiging kan, ten tweede, ook verklaard worden door de virtuele in plaats van de feitelijke interactie met de cobot. Het enkel lezen van een vignette met een cobotbeschrijving en het invullen van een vragenlijst door een participant is wellicht niet vergelijkbaar met het effectief kunnen uittesten van of werken met een reële cobot op de werkvloer en een te beperkte strategie om de accepteerbaarheid en tevens de verwachte baanbedreiging van een operator te beïnvloeden of veranderen. Ook presenteerde de eerste vraag geen definitie van robots (in tegenstelling tot de tweede vraag naar ervaren baanbedreiging die wel een definitie van cobots gaf), waardoor verschillen in interpretatie van wat een robot is en welke rol die kan hebben een alternatieve verklaring zou kunnen bieden voor de gevonden significante verschillen (binnen en tussen de deelsteekproeven).

\section{Accepteerbaarheid cobots en cobotfunctionaliteiten}

Wanneer we specifieker exploreerden naar de accepteerbaarheid van cobotfuntionaliteiten (vgl. OV2) ontdekten we dat operatoren vooral positief staan tegenover, bovenal, cobots die fysieke taken zouden uitvoeren en daarna cobots die aan kwaliteitscontrole doen. Toekomstige operatoren (vgl. OV3) waren enkel te vinden voor cobots die fysieke taken zouden uitvoeren. Cognitieve functionaliteiten en adaptieve functionaliteiten (op basis van mentale werkbelasting) kenden eerder een neutrale accepteerbaarheid - en cognitieve functionaliteiten vertoonden voor de toekomstige operatoren zelfs een eerder lage accepteerbaarheid. Opmerkelijk is dat fysieke, cognitieve en kwaliteitsfunctionaliteiten significant hoger werden ingeschat door de operatoren in vergelijking met de toekomstige operatoren. Adaptieve functionaliteiten werden gelijk ingeschat.

Een peiling naar de de accepteerbaarheid van cobots in het algemeen (vgl. OV2) toont dat operatoren deze evolutie als eerder positief inschatten, terwijl toekomstige operatoren hier een 
neutrale accepteerbaarheid vertoonden. Opnieuw scoorden de operatoren hierin significant hoger.

Deze bevindingen illustreren, net als in Takayama en collega's (2008), dat de operatoren in deze studie meer en andere functionaliteiten van cobots onderschrijven dan de typische dangerous, dirty and dull functionaliteiten van robots. Toch zien we enige conservativiteit wat betreft een cobot die ook sterke cognitieve (waarvan leidinggevende; zie de gebruikte items) taken zou verrichten en adaptief zou werken op basis van de gemeten mentale werkbelasting. Daarnaast is het opmerkelijk dat, ondanks dat toekomstige operatoren wat lager scoren op ervaren baanbedreiging, deze te recruteren toekomstige groep iets conservatiever staat tegenover cobots. Deze statistisch significante lagere accepteerbaarheid bij de toekomstige operatoren (d.w.z. studenten) zou een weerspiegeling kunnen zijn van hun nog beperkte ervaring met robots of nieuwe technologieën in het algemeen op een productievloer. Ook hun nog prille niveau van technologische geletterdheid, d.w.z. een lage 'technology readiness', zou dit effect kunnen verklaren. Daarenboven zouden deze resultaten kunnen suggereren dat een gebrek aan kennis over cobots en hoe deze geïmplementeerd kunnen worden in de eigen werkomgeving (zoals ook bij eerder onderzoek bij de algemene bevolking) tot een grotere terughoudendheid kan leiden. Operatoren bezitten namelijk de kennis om in te schatten hoe cobots al dan niet volledig betrouwbaar implementeerbaar zijn binnen hun werkomgeving.

Het exploreren naar verbanden tussen onze studievariabelen toont dat de accepteerbaarheid van de cobotfunctionaliteiten onderling positief correleren en op hun beurt positief correleren met cobot accepteerbaarheid. Ook technologische geletterdheid hangt positief samen met deze cobotvariabelen. Aanvankelijke en uiteindelijke baanbedreiging hangen positief samen, net als leeftijd met de accepteerbaarheid van de fysieke cobotfunctionaliteit. Toekomstig onderzoek 
zou met een grotere steekproef potentiële mediatoren kunnen onderzoeken, zoals bijvoorbeeld mediatie van kwaliteitscontrole in de relatie tussen technologische geletterdheid en cobot accepteerbaarheid.

Enkel (waarschijnlijk vanwege onze kleine steekproefgrootte) de kwaliteitsfunctionaliteit toonde vervolgens een voorspellend effect (positieve relatie) op de cobot accepteerbaarheid. Leeftijd had bijvoorbeeld geen effect, dit terwijl eerder onderzoek suggereert dat jongere mensen een beter begrip hebben van toekomstige technologie zoals AI en robotica en er zo zelfs meer argwanend tegenover kunnen zijn (Brougham \& Haar, 2018). Technologische geletterdheid toonde ook hier geen effect (evenzeer waarschijnlijk door onze kleine steekproefgrootte), maar toonde in onze bivariate correlatieanalyses wel een duidelijke positieve samenhang met de cobotvariabelen. Een positief verband tussen de technologische geletterdheid en accepteerbaarheid werd ook vastgelegd in de context van de adoptie van recentelijk ontwikkelde draagbare technologie die de mentale belasting van operatoren kan monitoren in de assembage-industrie (Van Acker et al., 2020). Deze bevindingen suggereren dat er betekenisvolle individuele verschillen kunnen zijn inzake de accepteerbaarheid van nieuwe technologiëen. Voor de uiteindelijke baanbedreiging werden geen significante voorspellers gevonden.

Toekomstig onderzoek naar mogelijks andere sterkere voorspellers van de algemene accepteerbaarheid van cobots door (toekomstige) werknemers is evenwel wenselijk, zoals bedrijfsklimaat (Patterson, Warr, \& West, 2004) (zie ook 'voluntariness' en 'subjective norm' in, Venkatesh \& Davis, 2000, en 'organization attributes' in, Venkatesh et al., 2016), baanzekerheid (Brougham \& Haar, 2018), werkgerelateerde stress (Alexandre et al., 2018) of taakkenmerken in de huidige job die relateren aan cobotfuntionaliteiten zoals het reeds frequent uitvoeren van fysieke taken (vgl. Morgeson \& Humphrey, 2006). Ook de bedrijfscommunicatie tijdens de initiële fase van de implementatie van een nieuwe technologie kan van invloed zijn 
op de mate van accepteerbaarheid van nieuwe technologiëen. Zo suggereert een recente pilootstudie van Van Acker en collega's (2020) dat de accepteerbaarheid bij werknemers groter kan zijn als het management in haar communicatie appelleert op intrinsieke doelen (bijv. het mogelijk gezondheidsbevorderdend effect van een nieuwe technologie) in een autonomieondersteunende werkcontext (bijv. discussie en inspraak is mogelijk) in vergelijking met een conditie waar de bedrijfscommunicatie appelleert op extrinsieke doelen (bijv. productiviteitsstijging door de nieuwe technologie) in een controlerende werkcontext (bijv. geen keuze of geen inspraak en verplicht gebruik). Het feit dat deze bevinding niet gerepliceerd kon worden in de gepreregistreerde studie van Van Acker en collega's (2020), suggereert het belang van de (bedrijfs)context waarin een nieuwe technologie geïmplementeerd wordt, naast de potentiële invloed van persoonsvariabelen (bijv. technologische geletterdheid) op de accepteerbaarheid van werknemers.

\subsection{Beperkingen}

Een aantal beperkingen, die vaak kenmerkend zijn voor exploratief onderzoek, dienen vermeld te worden.

Ten eerste, vallen de resultaten uit de hier beschreven exploratieve studie niet te generaliseren. Zo werden twee niet gematchte, niet representatieve kleine steekproeven van (toekomstige) operatoren bestudeerd. Ook de steekproef voor de thematische analyse was niet gematcht, terwijl binnen de steekproef ook veel variatie en zo vertekening kan voorkomen. Dit impliceert dat de beschreven resultaten niet kunnen gegeneraliseerd worden en maakt dat de resultaten en verschillen tussen de twee groepen door andere factoren (bijv. steekproefkenmeken) of op alternatieve wijzen kunnen verklaard worden. Waar de bedrijven niet noodzakelijk representatief zijn voor andere Vlaamse of Nederlandse maakbedrijven, zijn ook de bevraagde operatoren mogelijk niet representatief voor alle operatoren in beide (en andere) bedrijven. Hier 
werden de operatoren door hun oversten gevraagd deel te nemen, zodat zich een selectie kan hebben voorgedaan van enkel operatoren met reeds een zekere bereidwilligheid tot verandering in de productieomgeving of die reeds interesse hadden in cobots. Tot slot dient ook de generaliseerbaarheid van de Vlaamse context naar de Nederandse en andere contexten met representatieve steekproeven verkend te worden, daar de lokale werkgelegenheid en type industrie (bijv. de pharmaceutische industrie) volledig andere percepties, motivaties en graad van technologisering kan bevatten.

Ten tweede kan ook sociale wenselijkheid bij het antwoorden een significante rol hebben gespeeld. Zo werd ook geen rekening gehouden met het type arbeidsovereeenkomst (vast vs. tijdelijk werkcontract) van de participant. Mogelijk antwoorden werknemers met een tijdelijk contract meer sociaal wenselijk in functie van baanbehoud of net minder sociaal wenselijk omdat men niet op dergelijke lange termijn redeneert over nieuwe technologieën. Daarnaast kan het gebruik van een zelf-rapporteringsvragenlijst ook sociale wenselijkheid in de antwoorden hebben bevorderd, ondanks dat volledige anonimiteit gegarandeerd werd en dat operatoren deze onderzoekscontext ook net als een moment konden zien om hun bezorgdheden aan een neutrale partij te ventileren. Verder onderzoek in specifieke contexten (bijv. een bedrijfssector of een beroepsgroep) met concrete nieuwe technologieën waarmee participanten effectief in interactie kunnen treden (bijv. fysiek uitproberen) is dan ook wenselijk. Opnieuw kunnen user-centered design methodieken potentieel een toegevoegde waarde bieden (Gould \& Lewis, 1985; Hoecherl et al., 2018).

Ten derde zorgden de praktische voowaarden voor data-afname ook voor een beperking in de gebruikte materialen. Het was namelijk zo dat we door de beperkte beschikbare tijd met de (toekomstige) operatoren een selectie van variabelen moesten maken die we op basis van de 
wetenschappelijke literatuur en in overleg met ondermeer de deelnemende bedrijven als meest opportuun zagen. Ook telden onze meetschalen maar enkele items (o.a. technologische geletterdheid en cobot accepteerbaarheid) en viel de betrouwbaarheid van de technologische geletterdheid laag uit, mogelijk doordat het aantal items te beperkt was of door de vertaling naar het Nederlands. Toekomstig onderzoek kan bijvoorbeeld ook de relatie met persoonlijkheid bestuderen (Gessl, Schlögl, \& Mevenkamp, 2019) of zelfs de antropomorfisering van cobots (d.w.z. het toekennen van menselijke eigenschappen aan cobots) (Sauppé \& Mutlu, 2015; Yogeeswaran et al., 2016). Door het gebrek aan beschikbare literatuur inzake deze recent ontwikkelde technologie (d.w.z. cobots) hadden we ook geen sterke theoretische basis om hypotheses te formuleren, laat staan om er een structureel model of theorie rond op te bouwen. Dit onderzoek is dus een pragmatische eerste exploratie die niettemin interessante inzichten heeft opgeleverd.

Tot slot dienen we ook op te merken dat de antwoorden veel variabiliteit vertoonden tussen operatoren. Toekomstig onderzoek en zeker initiatieven tot effectieve implementatie van cobots houdt dus best rekening met een mogelijk zeer gepersonaliseerd acceptatietraject. In bepaalde mate biedt dergelijke technologie ook per definitie die mogelijkheid. Zeker in het licht van de ervaren baanbedreiging lijkt personalisatie een cruciale toekomstige stap en interessante onderzoekslijn.

Ondanks bovenvermelde studiebeperkingen hopen we dat onze exploratief bekomen onderzoeksresultaten mede een aanzet geven tot verder onderzoek naar de accepteerbaarheid en acceptatie van cobots en andere nieuwe technologieën in het bedrijfsleven in Vlaanderen en Nederland. Op die manier hopen de auteurs mee te helpen aan contextualiseerbare richtlijnen 
en adviezen voor de toekomstige implementatie en adoptie van cobots die zowel de bedrijven als de operatoren ten goede komen.

\section{Conclusie}

De gepresenteerde studie verkende met een vragenlijst en semi-gestructureerd interview de ervaren baanbedreiging en accepteerbaarheid bij (toekomstige) operatoren van de toekomstige introductie van cobots op de industriële werkvloer. Verrassend genoeg bleek de ervaren baanbedreiging bij aanvang van de studie beperkt te zijn en steeg deze wat op het einde van de vragenlijst - wanneer de participanten meer hadden geleerd over cobots - naar nog steeds een neutrale inschatting. De betrouwbaarheid en capaciteiten van cobots werd hierbij in twijfel getrokken. De resultaten toonden verder aan dat interesse in de functionaliteiten van cobots verder gaat dan het helpen bij de typische 'dangerous, dirty and dull' taken. Cobots die veel cognitieve en adaptieve taken zouden verrichten werden dan eerder met terughoudendheid gepercipieerd. De algemene accepteerbaarheid van cobots werd door de operatoren eerder positief ingeschat. Opmerkelijk, toekomstige operatoren (d.w.z. studenten) vertoonden, in vergelijking met reeds tewerkgestelde operatoren, een eerder neutrale accepteerbaarheid voor zowel cobotfunctionaliteiten als cobots in het algemeen.

\section{Praktijkbox}

Wat betekenen de resultaten voor de praktijk?

- Tewerkgestelde operatoren in de maakindustrie en potentieel toekomstige operatoren ervaren een beperkte baanbedreiging door collaboratieve robots (cobots) in Vlaanderen, maar deze ervaring kan wel wat stijgen naarmate ze meer kennismaken met de mogelijke functionaliteiten van cobots. 
- Tewerkgestelde operatoren staan eerder positief tegenover toekomstige samenwerking met cobots, ook al werken ze momenteel nog niet met cobots samen. Toekomstige operatoren staan hier eerder neutraal tegenover.

- Cobots kunnen volgens tewerkgestelde operatoren en potentieel toekomstige operatoren ingezet worden voor meer dan alleen maar typische 'gevaarlijke, saaie en vuile' werktaken, maar operatoren staan eerder neutraal tegenover het idee dat cobots veel denkwerk op zich zouden nemen of zich zouden aanpassen aan de mentale werkbelasting van de operator.

- De betrouwbaarheid en capaciteiten van cobots wordt nog in twijfel getrokken door tewerkgestelde operatoren, waardoor ze (nog) niet vrezen voor het behoud van hun baan.

\section{Noten}

${ }^{1}$ Dit onderzoek werd gesteund door het strategisch onderzoekscentrum voor de maakindustrie Flanders Make, Oude Diestersebaan, 133, 3920 Lommel, België, als deel van het SBO-project 'Augmented workers using smart robots in a manufactring cell (Yves)'. Daarnaast wensen de auteurs ook hun uitgebreide dank te uiten aan de twee bedrijven en de drie scholen voor hun medewerking en de zeer efficiënte organisatie. Tot slot danken we ook studenten Industrieel Ontwerp (UGent) Frauke Destrijcker, François Desmet en Pieterjan Van der Borght, betrokken in dit onderzoek, voor hun inzet en toewijding.

${ }^{2}$ De resultaten voor de factoranalyses zijn terug te vinden op https://osf.io/rx3bq/?view_only=4b464cddff2d4c5f97dd32570573136d

\section{Literatuur}

Ajoudani, A., Zanchettin, A. M., Ivaldi, S., Albu-Schäffer, A., Kosuge, K., \& Khatib, O. (2018). Progress and prospects of the human-robot collaboration. Autonomous Robots, 
42(5), 957-975. https://doi.org/10.1007/s10514-017-9677-2

Ajzen, I. (1991). The theory of planned behavior. Organizational Behavior and Human Decision Processes, 50, 179-211.

Ajzen, I. (2001). Nature and operation of attitudes. Annual Review of Psychology, 52(1), $27-$ 58. https://doi.org/10.1146/annurev.psych.52.1.27

Akella, P., Peshkin, M., Colgate, E., Wannasuphoprasit, W., Nagesh, N., Wells, J., ... Peacock, B. (1999). Cobots for the automobile assembly line. In Proceedings 1999 IEEE International Conference on Robotics and Automation (Cat. No.99CH36288C) (Vol. 1, pp. 728-733). Detroit, MI, USA: IEEE. https://doi.org/10.1109/ROBOT.1999.770061

Al-ahmari, A. M., Abidi, M. H., \& Ahmad, A. (2016). Development of a virtual manufacturing assembly simulation system. Advances in Mechanical Engineering, 8(3), 1-13. https://doi.org/10.1177/1687814016639824

Alexandre, B., Reynaud, E., Osiurak, F., \& Navarro, J. (2018). Acceptance and acceptability criteria: A literature review. Cognition, Technology and Work, 20(2), 165-177. https://doi.org/10.1007/s10111-018-0459-1

Anandan, T. M. (2013). The end of separation: Man and robot as collaborative coworkers on the factory floor. Retrieved from https://www.robotics.org/content-detail.cfm/IndustrialRobotics-Industry-Insights/The-End-of-Separation-Man-and-Robot-as-CollaborativeCoworkers-on-the-Factory-Floor/content_id/4140

Arntz, M., Gregory, T., \& Zierahn, U. (2016). The risk of automation for jobs in OECD countries: A comparative analysis. In Working paper (Vol. 189, p. 34). OECD Publishing. https://doi.org/10.1787/5jlz9h56dvq7-en

Bauer, A., Ollherr, D., \& Buss, M. (2008). Human-robot collaboration: A survey. International Journal of Humanoid Robotics, 05(01), 47-66. https://doi.org/10.1142/S0219843608001303 
Biassoni, F., Ruscio, D., \& Ciceri, R. (2016). Limitations and automation: The role of information about device-specific features in ADAS acceptability. Safety Science, 85, 179-186. https://doi.org/10.1016/j.ssci.2016.01.017

Bläsing, D., Hinrichsen, S., \& Bornewasser, M. (2020). Reduction of cognitive load in complex assembly systems. In T. Ahram, R. Taiar, V. Gremeaux-Bader, \& K. Aminian (Eds.), Human Interaction, Emerging Technologies and Future Applications II. IHIET 2020. Advances in Intelligent Systems and Computing. vol 1152 (pp. 495-500). Cham: Springer. https://doi.org/10.1007/978-3-030-44267-5_75

Bogue, R. (2016). Europe continues to lead the way in the collaborative robot business. Industrial Robot, 43(1), 6-11. https://doi.org/10.1108/IR-10-2015-0195

Booker, J. D., Swift, K. G., \& Brown, N. J. (2005). Designing for assembly quality: Strategies, guidelines and techniques. Journal of Engineering Design, 16(3), 279-295. https://doi.org/10.1080/09544820500126672

Bröhl, C., Nelles, J., Brandl, C., Mertens, A., \& Schlick, C. M. (2016). TAM reloaded: A technology acceptance model for human-robot cooperation in production systems. In C. Stephanidis (Ed.), HCII 2016 Posters, Part I, CCIS (Vol. 617, pp. 97-103). Cham: Springer International Publishing. https://doi.org/10.1007/978-3-319-40548-3

Brolin, A., Thorvald, P., \& Case, K. (2017). Experimental study of cognitive aspects affecting human performance in manual assembly. Production and Manufacturing Research, 5(1), 141-163. https://doi.org/10.1080/21693277.2017.1374893

Brougham, D., \& Haar, J. (2018). Smart Technology, Artificial Intelligence, Robotics, and Algorithms (STARA): Employees' perceptions of our future workplace. Journal of Management \& Organization, 24(2), 239-257. https://doi.org/10.1017/jmo.2016.55

Brynjolfsson, E., Mitchell, T., \& Rock, D. (2018). What can machines learn, and what does it mean for occupations and the economy? AEA Papers and Proceedings, 108, 43-47. 
https://doi.org/10.1257/pandp.20181019

Davis, F. D. (1989). Perceived usefulness, perceived ease of use, and user acceptance of information technology. MIS Quarterly, 13(3), 319-340.

Deci, E. L., Olafsen, A. H., \& Ryan, R. M. (2017). Self-determination theory in work organizations: The state of a science. Annual Review of Organizational Psychology and Organizational Behavior, 4(1), 19-43. https://doi.org/10.1146/annurev-orgpsych032516-113108

Elprama, S. A., El Makrini, I., Vanderborght, B., \& Jacobs, A. (2016). Acceptance of collaborative robots by factory workers: A pilot study on the importance of social cues of anthropomorphic robots. In 25th IEEE International Symposium on Robot and Human Interactive Communication (ROMAN), 2016 (pp. 919-919). New York.

Elprama, S. A., Jewell, C. I. C., Jacobs, A., El Makrini, I., \& Vanderborght, B. (2017). Attitudes of factory workers towards industrial and collaborative robots. ACM/IEEE International Conference on Human-Robot Interaction, 113-114. https://doi.org/10.1145/3029798.3038309

Erol, S., Jäger, A., Hold, P., Ott, K., \& Sihn, W. (2016). Tangible industry 4.0: A scenariobased approach to learning for the future of production. Procedia CIRP, 54, 13-18. https://doi.org/10.1016/j.procir.2016.03.162

Festinger, L. (1954). A theory of social comparison processes. Human Relations, 7(2), 117140. https://doi.org/10.1177/001872675400700202

Fletcher, S. R., Johnson, T. ., \& Larreina, J. (2019). Putting people and robots together in manufacturing: Are we ready? In M. Aldinhas Ferreira, J. Silva Sequeira, G. Singh Virk, M. Tokhi, \& E. E. Kadar (Eds.), Robotics and Well-Being. Intelligent Systems, Control and Automation: Science and Engineering (pp. 135-147). Cham: Springer. https://doi.org/10.1007/978-3-030-12524-0_12 
Gessl, A. S., Schlögl, S., \& Mevenkamp, N. (2019). On the perceptions and acceptance of artificially intelligent robotics and the psychology of the future elderly. Behaviour and Information Technology, 38(11), 1068-1087.

https://doi.org/10.1080/0144929X.2019.1566499

Gombolay, M. C., Gutierrez, R. A., Clarke, S. G., Sturla, G. F., \& Shah, J. A. (2015).

Decision-making authority, team efficiency and human worker satisfaction in mixed human-robot teams. Autonomous Robots, 39(3), 293-312. https://doi.org/10.1007/s10514-015-9457-9

Gould, J. D., \& Lewis, C. (1985). Designing for usability: Key principles and what designers think. Communications of the ACM, 28(3), 300-311. https://doi.org/10.1145/3166.3170

Granulo, A., Fuchs, C., \& Puntoni, S. (2019). Psychological reactions to human versus robotic job replacement. Nature Human Behaviour, 3(10), 1062-1069. https://doi.org/10.1038/s41562-019-0670-y

Hoecherl, J., Schmargendorf, M., Wrede, B., \& Schlegl, T. (2018). User-centered design of multimodal robot feedback for cobots of human-robot working cells in industrial production contexts. In SR 2018; 50th International Symposium on Robotics (pp. 1-8). Munich, Germany.

Hold, P., Ranz, F., Sihn, W., \& Hummel, V. (2016). Planning operator support in cyberphysical assembly systems. IFAC-PapersOnLine, 49(32), 60-65. https://doi.org/10.1016/j.ifacol.2016.12.190

Jacobs, A., Tytgat, L., Maus, M., Meeusen, R., \& Vanderborght, B. (2019). Homo Roboticus. VUB Press.

Klein, K. J., \& Sorra, J. S. (1996). The challenge of innovation implementation. The Academy of Management Review, 21(4), 1055. https://doi.org/10.2307/259164

Landi, C. T., Villani, V., Ferraguti, F., Sabattini, L., Secchi, C., \& Fantuzzi, C. (2018). 
Relieving operators 'workload: Towards affective robotics in industrial scenarios. Mechatronics, 54(August), 144-154. https://doi.org/10.1016/j.mechatronics.2018.07.012

Longo, F., Nicoletti, L., \& Padovano, A. (2017). Smart operators in industry 4.0: A humancentered approach to enhance operators' capabilities and competencies within the new smart factory context. Computers and Industrial Engineering, 113, 144-159. https://doi.org/10.1016/j.cie.2017.09.016

Makrini, I. El, Merckaert, K., Lefeber, D., \& Vanderborght, B. (2017). Design of a collaborative architecture for human-robot assembly tasks. In 2017 IEEE/RSJ International Conference on Intelligent Robots and Systems (IROS) (pp. 1624-1629). Vancouver, BC.

Maurtua, I., Ibarguren, A., Kildal, J., Susperregi, L., \& Sierra, B. (2017). Human-robot collaboration in industrial applications: Safety, interaction and trust. International Journal of Advanced Robotic Systems, 14(4), 1-10. https://doi.org/10.1177/1729881417716010

Maus, M., Vanderborght, B., Meeusen, R., \& Jacobs, A. (2018). Zullen we op de “De Dag van de Arbeid” vanaf nu "De Dag van de Robot" vieren? Retrieved from https://www.vrt.be/vrtnws/nl/2018/04/30/opinie-michel-maus-en-co-daag-van-de-robot/

McGaughey, E. (2018). Will robots automate your job away? Full employment, basic income, and economic democracy. Centre for Business Research, University of Cambridge. Working Paper No. 496, 1-34. https://doi.org/10.2139/ssrn.3044448

Morgeson, F. P., \& Humphrey, S. E. (2006). The Work Design Questionnaire (WDQ): Developing and validating a comprehensive measure for assessing job design and the nature of work. Journal of Applied Psychology, 91(6), 1321-1339. https://doi.org/10.1037/0021-9010.91.6.1321

Nowell, L. S., Norris, J. M., White, D. E., \& Moules, N. J. (2017). Thematic analysis: Striving 
to meet the trustworthiness criteria. International Journal of Qualitative Methods, 16, 113. https://doi.org/10.1177/1609406917733847

Oztemel, E., \& Gursev, S. (2020). Literature review of Industry 4.0 and related technologies. Journal of Intelligent Manufacturing, 31(1), 127-182. https://doi.org/10.1007/s10845$018-1433-8$

Parasuraman, A. (2000). Technology Readiness Index (TRI): A multiple-item scale to measure readiness to embrace new technologies. Journal of Service Research, 2(4), 307320. https://doi.org/10.1177/109467050024001

Patterson, M., Warr, P., \& West, M. (2004). Organizational climate and company productivity: The role of employee affect and employee level. Journal of Occupational and Organizational Psychology, 77, 193-216. Retrieved from https://doi.org/10.1348/096317904774202144

Peternel, L., Tsagarakis, N., Caldwell, D., \& Ajoudani, A. (2016). Adaptation of robot physical behaviour to human fatigue in human-robot co-manipulation. IEEE-RAS International Conference on Humanoid Robots, 489-494. https://doi.org/10.1109/HUMANOIDS.2016.7803320

QSR. (2018). NVivo qualitative data analysis software. QSR International Pty Ltd. Version 12.

Rogers, E. M. (1995). Diffusion of innovations (4th ed.). New York, NY: Free Press.

Russell, S. J., \& Norvig, P. (2009). Artificial intelligence: A modern approach. (Prentice Hall, Ed.) (3rd ed.). Upper Saddle River, New Jersey.

Sauppé, A., \& Mutlu, B. (2015). The social impact of a robot co-worker in industrial settings. Conference on Human Factors in Computing Systems - Proceedings, 2015-April, 36133622. https://doi.org/10.1145/2702123.2702181

Shalin, V. L., Prabhu, G. V., \& Helander, M. G. (1996). A cognitive perspective on manual 
assembly. Ergonomics, 39(1), 108-127. https://doi.org/10.1080/00140139608964438

Tabachnick, B. G., \& Fidell, L. S. (2013). Using multivariate statistics (6th ed.). Boston, MA: Pearson Education.

Takayama, L., Ju, W., \& Nass, C. (2008). Beyond dirty, dangerous and dull: What everyday people think robots should do. In HRI’08 (pp. 12-15).

Tesser, A. (1988). Toward a self-evaluation maintenance model of social behavior. Advances in Experimental Social Psychology, 21, 181-227. https://doi.org/10.1016/S00652601(08)60227-0

TNS Opinion \& Social. (2015). Special Eurobarometer 427 / Wave EB82.4 - Autonomous systems. European Commission, Directorate-General for Networks, Content and Technology (DG CONNECT) \& Directorate-General for Communication (DG COMM). Retrieved from http://ec.europa.eu/public_opinion/index_en.htm

Um, J., Lyons, A., Lam, H. K. S., Cheng, T. C. E., \& Dominguez-Pery, C. (2017). Product variety management and supply chain performance: A capability perspective on their relationships and competitiveness implications. International Journal of Production Economics, 187, 15-26. https://doi.org/10.1016/j.ijpe.2017.02.005

Van Acker, B. B., Conradie, P. D., Vlerick, P., \& Saldien, J. (2020). Employee acceptability of wearable mental workload monitoring: exploring effects of framing the goal and context in corporate communication. Cognition, Technology \& Work. https://doi.org/10.1007/s10111-020-00633-0

Venkatesh, V., \& Davis, F. D. (2000). A theoretical extension of the technology acceptance model: four Fongitudinal field studies. Management Science, 46(2), 186-204. https://doi.org/10.1287/mnsc.46.2.186.11926

Venkatesh, V., Thong, J. Y. L., \& Xu, X. (2016). Unified theory of acceptance and use of technology: A synthesis and the road ahead. Journal of the Association for Information 
Systems, 17(5), 328-376.

Victorino, L., Karniouchina, E., \& Verma, R. (2009). Exploring the use of the abbreviated technology readiness index for hotel customer segmentation. Cornell Hospitality Quarterly, 50(3), 342-359. https://doi.org/10.1177/1938965509336809

Villani, V., Pini, F., Leali, F., \& Secchi, C. (2018). Survey on human - robot collaboration in industrial settings: Safety, intuitive interfaces and applications. Mechatronics, 55(March), 248-266. https://doi.org/10.1016/j.mechatronics.2018.02.009

Vlassenroot, S., Brookhuis, K., Marchau, V., \& Witlox, F. (2010). Towards defining a unified concept for the acceptability of Intelligent Transport Systems (ITS): A conceptual analysis based on the case of Intelligent Speed Adaptation (ISA). Transportation Research Part F: Traffic Psychology and Behaviour, 13(3), 164-178. https://doi.org/10.1016/j.trf.2010.02.001

Walczuch, R., Lemmink, J., \& Streukens, S. (2007). The effect of service employees’ technology readiness on technology acceptance. Information and Management, 44(2), 206-215. https://doi.org/10.1016/j.im.2006.12.005

Wan, X., \& Sanders, N. R. (2017). The negative impact of product variety: Forecast bias, inventory levels, and the role of vertical integration. International Journal of Production Economics, 186, 123-131. https://doi.org/10.1016/j.ijpe.2017.02.002

Weiss, A., \& Huber, A. (2016). User experience of a smart factory robot: Assembly line workers demand adaptive robots. In AISB2016: Proceedings of the 5th International Symposium on New Frontiers in Human-Robot Interaction. (pp. 1-3).

Wollschlaeger, M., Sauter, T., \& Jasperneite, J. (2017). The future of industrial communication: automation networks in the era of the internet of things and industry 4.0. IEEE Industrial Electronics Magazine, 11(1), 17-27.

https://doi.org/10.1109/MIE.2017.2649104 
Xu, L. Da, Xu, E. L., \& Li, L. (2018). Industry 4.0: State of the art and future trends. International Journal of Production Research, 7543, 1-22. https://doi.org/10.1080/00207543.2018.1444806

Yogeeswaran, K., Złotowski, J., Livingstone, M., Bartneck, C., Sumioka, H., \& Ishiguro, H. (2016). The interactive effects of robot anthropomorphism and robot ability on perceived threat and support for robotics research. Journal of Human-Robot Interaction, 5(2), 29. https://doi.org/10.5898/jhri.5.2.yogeeswaran

Young, M. S., Brookhuis, K. A., Wickens, C. D., \& Hancock, P. A. (2014). State of science: Mental workload in ergonomics. Ergonomics, 58(1), 1-17. https://doi.org/10.1080/00140139.2014.956151

Złotowski, J., Yogeeswaran, K., \& Bartneck, C. (2017). Can we control it? Autonomous robots threaten human identity, uniqueness, safety, and resources. International Journal of Human-Computer Studies, 100, 48-54. https://doi.org/10.1016/j.ijhcs.2016.12.008

English title: An explorative study on the acceptability of industrial cobots in (future) operators

English summary: Collaborative robots ('cobots') will have a prominent place within the emerging fourth industrial revolution. Today, it is however unknown how operators relate to this cobot (r)evolution. Here, we deployed a survey and a short semi-structured interview to exploratively gauge the perceived job threat by and the acceptability of cobots and their cobot functionalities within (future) operators $(N=83)$. Results showed that the initial job threat was limited. This peception did raise significantly toward the end of the survey - where participants had learned more about cobots - to a neutral score still, possibly because (future) operators doubt the reliability and capabilities of cobots. Next to this, a higher acceptability was found for cobot functionalities covering physical tasks and quality control, while cognitively advanced and adaptive cobots yielded rather neutral acceptability. The general acceptability 
of cobots panned out rather positive for operators. Remarkably, future operators (students) rated most of these variables slightly lower, compared to currently employed operators. Limitations and implications for the acceptability and acceptance of this promising technology are formulated.

Key words: cobot, operator, use intention, technology acceptance, acceptability

\section{Bijlage: Items gebruikt voor de gemeten variabelen}

\section{Technologische geletterdheid}

1. In het algemeen ben ik één van de eersten in mijn vriendenkring om nieuwe technologie aan te schaffen als het uit komt.

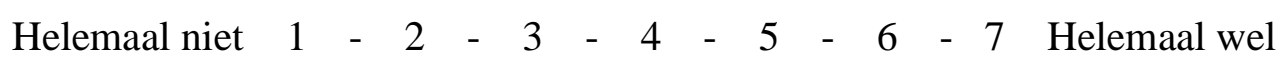

2. Nieuwe technologie draagt bij tot een betere kwaliteit van leven.

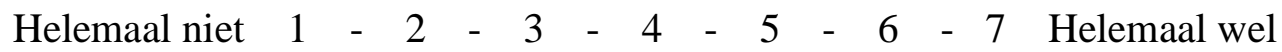

3. Ik heb er vertrouwen in zaken te doen met een winkel die enkel on-line te bereiken

is.

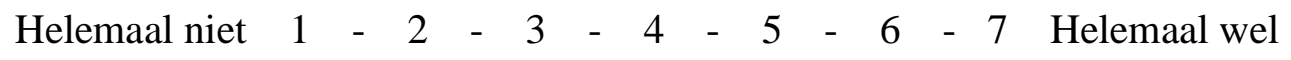

4. Nieuwe technologie maakt het te makkelijk voor overheden of bedrijven om mensen te bespioneren.

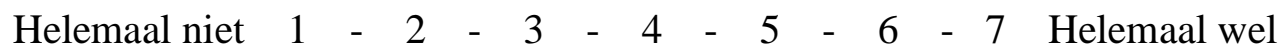




\section{Overige persoonsvariabelen}

1. Hoelang beoefen je dit beroep bij dit bedrijf al?

$$
\text { ... jaar }
$$

2. Hoeveel ervaring heeft $\mathrm{u}$ met het samenwerken met robots?

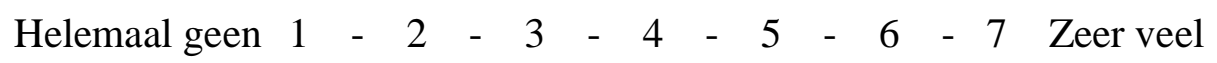

3. Weet $u$ wat een cobot is?

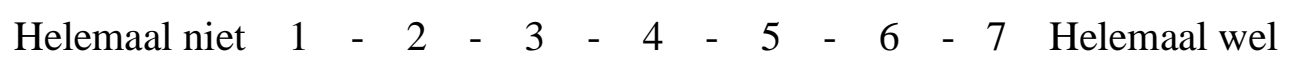

\section{Initiële ervaren baanbedreiging}

1. Ik vind robots een bedreiging voor het behouden van mijn job:

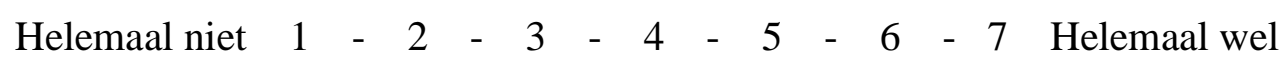

\section{Uiteindelijke ervaren baanbedreiging}

1. Indien zo'n cobot volledig zou voldoen aan jouw wensen, in welke mate zou je deze cobot een bedreiging vinden voor het behouden van je job?

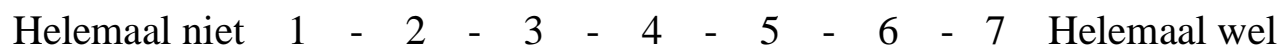




\section{Accepteerbaarheid cobotfunctionaliteiten}

1. Een cobot zou taken mogen uitvoeren die zich vaak herhalen.

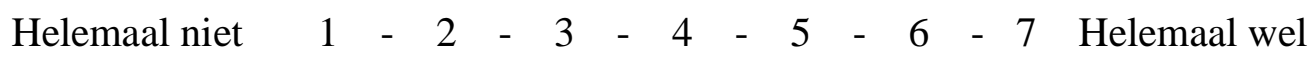

2. Een cobot zou taken mogen uitvoeren die fysiek zwaar zijn.

Helemaal niet $\quad \begin{array}{lllllllllllll} & - & 2 & - & 3 & - & 4 & - & 5 & - & 6 & - & \end{array}$ Helemaal wel

3. Een cobot zou taken mogen uitvoeren die veel denkwerk vragen.

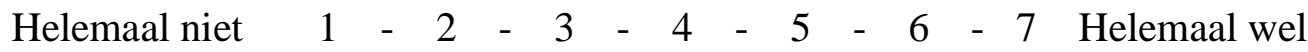

4. Een cobot zou taken mogen uitvoeren die precisiewerk vragen.

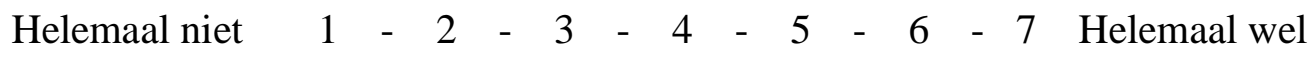

5. Een cobot zou mij zaken mogen vertellen om instructies overbodig te maken.

Helemaal niet $\quad \begin{array}{lllllllllllll} & - & 2 & - & 3 & - & 4 & - & 5 & - & 6 & - & \end{array}$ Helemaal wel

6. Een cobot zou mogen controleren of ik fouten aan het maken ben.

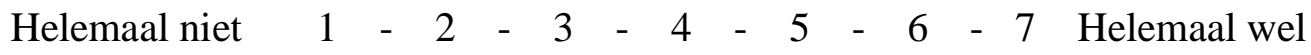


7. Een cobot zou mij doorheen mijn taakuitvoering mogen leiden, zodat ik altijd weet wat te doen.

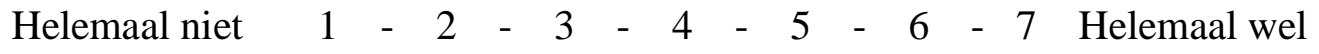

8. Een cobot zou zelf mogen beslissen om aan een taak te beginnen.

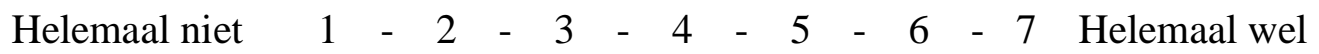

9. Ik zou liever hebben dat een cobot mij op fouten wijst in de plaats van dat mijn overste dat doet.

Helemaal niet $1-2-2-3-4-5-5-6-7$ Helemaal wel

10. Ik zou het leuk vinden om enkele cobots voor mij te laten werken.

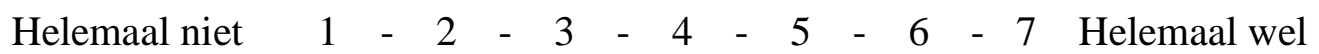

Geef aan in welke mate het meten van je mentale vermoeidheid volgens jou gebruikt zou mogen worden om:

1. ... vervolgens bepaalde taken over te nemen of wat meer taken aan jou over te laten.

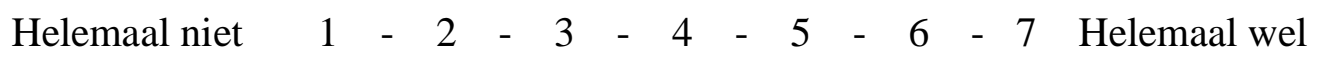

2. ... vervolgens het werktempo aan te passen. 


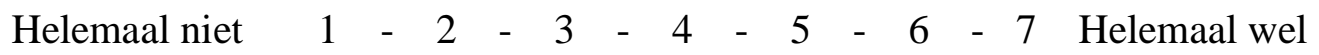

3. ... mijn werk vervolgens meer of minder te controleren op fouten.

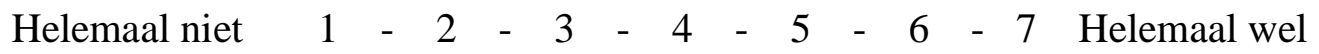

4. .... mij vervolgens meer of minder instructies te geven.

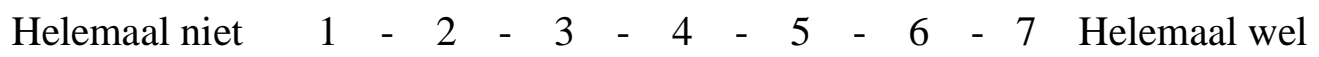

5. ... mij vervolgens te waarschuwen zodat ik zelf kan beslissen iets aan de mentale vermoeidheid te doen.

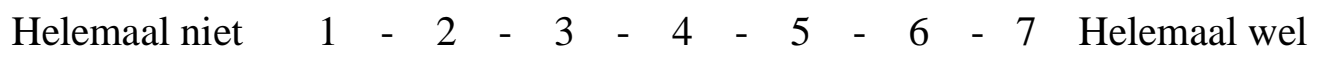

6. Ik zou er vertrouwen in hebben dat mijn gegevens omtrent mijn mentale vermoeidheid anoniem zouden blijven en niet voor andere doeleinden gebruikt zouden worden.

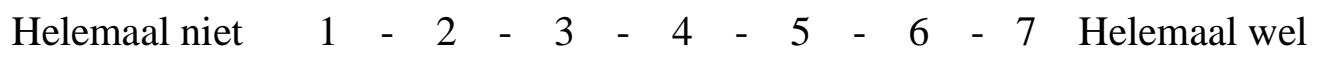

\section{Accepteerbaarheid cobots algemeen}

1. Indien zo'n cobot volledig zou voldoen aan jouw wensen, in welke mate denk je dat deze cobot je zou kunnen helpen in je job?

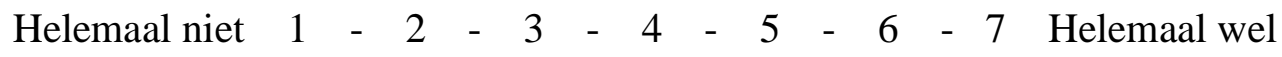


2. Indien zo'n cobot volledig zou voldoen aan jouw wensen, in welke mate zou je met zo'n cobot willen samenwerken?

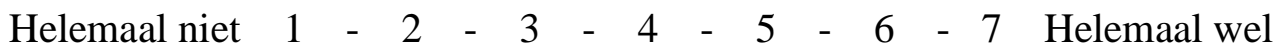

